\title{
Morphine Protects against Intracellular Amyloid Toxicity by Inducing Estradiol Release and Upregulation of Hsp70
}

\author{
Jia Cui, ${ }^{1}$ Yunfeng Wang, ${ }^{1}$ Qiping Dong, ${ }^{1}$ Shimin Wu, ${ }^{2}$ Xianzhong Xiao, ${ }^{3}$ Jianying Hu, ${ }^{2}$ Zhen Chai, ${ }^{1}$ and Yan Zhang ${ }^{1}$ \\ ${ }^{1}$ Laboratory of Neurobiology and State Key Laboratory of Biomembrane and Membrane Biotechnology, College of Life Sciences and ${ }^{2}$ College of Urban and \\ Environmental Sciences, Peking University, Beijing 100871, China, and ${ }^{3}$ Department of Pathophysiology, Central South University, Hunan 410083, China
}

Certain experimental models support morphine can play a beneficial role against damage in the neuronal system. In this study, we find morphine as well as endomorphin- 1 and endomorphin- 2 can protect against intracellular amyloid $\beta$ (iA $\beta$ ) toxicity in human and rat primary neuronal cultures and in rat brains in vivo. Morphine reverses the electrophysiological changes induced by iA $\beta$, including current density, resting membrane potential and capacitance. Also morphine improves the spatial memory performance in rats infected by iA $\beta$ packaged virus and in APP/PS1 mice in Morris water maze tests. Morphine protection is mediated through inducing estradiol release in hippocampal neurons measured by ELISA and liquid chromatography-mass spectrometry, possibly by increasing P450 cytochrome aromatase activity. Released estradiol induces upregulation of heat shock protein 70 (Hsp70). Hsp70 protects against intracellular amyloid toxicity by rescuing proteasomal activity which is impaired by $\mathrm{iA} \beta$. This is the first time, to our knowledge, that induction of estradiol release in hippocampal neurons by morphine is reported. Our data may contribute to both Alzheimer's disease therapy and pain clinics where morphine is widely used.

\section{Introduction}

Morphine has been a widely used medicine in clinics for a long time as an effective treatment for diarrhea and pain (Zhang et al., 2008). Several lines of evidence suggest that morphine may be neuroprotective. In rat neonatal hypoxia-ischemia model, morphine application immediately after hypoxia decreases infarct volume in the brain (Zhou et al., 1998). In zebrafish embryos, morphine, at certain concentrations, enhances neuron proliferation, increases the number of certain neuronal populations, and protects against glutamate damage in motor neurons and Pax-6-positive neurons in vivo (Sanchez-Simon et al., 2010). Morphine is found to be protective against microglia-mediated lipopolysccharide- or

\footnotetext{
Received July 30, 2011; revised Sept. 6, 2011; accepted Sept. 13, 2011.

Author contributions: Y.Z. designed research; J.C., Y.W., Q.D., and S.W. performed research; X.X. contributed unpublished reagents/analytic tools; J.H., Z.C., and Y.Z. analyzed data; Y.Z. wrote the paper.

This work was supported by the National Program of Basic Research sponsored by the Ministry of Science and Technology of China (2009CB941301), a Roche research grant, Peking University President Research Grant, and a Ministry of Education recruiting research grant. The appropriate approvals and procedures were used concerning human subjects and animals. The protocol was approved by the Peking University Medical School Institutional Review Board (IRB00001052-0572). We thank Drs. Longchuan Yu, Yong Cheng (Peking University, Beijing, China), and Nan Sui (Institute of Psychology, Chinese Academy of Sciences) for assistance with the water maze test; Dr. Meizhi Liu (Peking Union Medical College Hospital) for technical assistance with measuring estrogen concentrations; Dr. Zehui Gong (Institute for Military Medical Sciences) for providing the BSA-M; Dr. Yongfeng Shang (School of Medicine, Peking University) for providing MCF-7 and MDA-MB231 cell lines; Dr. Richard Day (School of Medicine, University of Virginia, Charlottesville, VA) for providing PKAI and PKAIM constructs; Dr. Ramunas Vabulas (Max Planck Institute of Biochemistry, Martinsried, Germany) for providing the Ub-EGFP construct; Mr. Yu Tian (Technical Analysis Department, Beijing Municipal Public Security Bureau, Xuanwu Division) for technical assistance of measuring testosterone concentrations; Ms. Qiuyue Chen (College of Life Sciences, Peking University) for technical assistance with luciferase activity measurement; and Drs. Sam Sisodia (University of Chicago) and Karl Herrup (Rutgers University) for reading this manuscript and giving thoughtful suggestions.

The authors declare no competing financial interests.

Correspondence should be addressed to either Dr. Yan Zhang or Dr. Zhen Chai, College of Life Sciences, Room 219, Peking University, Beijing, 100871, China. E-mail: yanzhang@pku.edu.cn or zhenchai@pku.edu.cn.

DOI:10.1523/JNEUROSCI.3915-11.2011

Copyright $\odot 2011$ the authors $\quad 0270-6474 / 11 / 3116227-14 \$ 15.00 / 0$
}

1-methyl-4-phenylpyridinium-induced dopaminergic neurotoxicity in rat primary mesencephalic neuron/glia cultures (Qian et al., 2007). In rat neuronal/glial cultures, morphine is reported to prevent cell death induced by HIV envelope glycoprotein gp120IIIB or BaL (Avdoshina et al., 2010). Exogenous morphine preincubation improves the population of spike amplitudes of evoked field potentials, indicating that preconditioning with morphine might be neuroprotective (Ammon-Treiber et al., 2005). Morphine preconditioning induces opioid receptor-dependent neuroprotection against ischemia in rats and reduced ischemia-induced cell death in the CA1 regions of hippocampal slices (Zhao et al., 2006). In mouse hippocampal slices with oxygen-glucose deprivation, morphine preconditioning improves neuronal cell survival rate through protein kinase $\mathrm{C} \varepsilon(\mathrm{PKC} \varepsilon)$ (Liu et al., 2008).

Alzheimer's disease (AD) is characterized by three major hallmarks: extracellular senile plaques composed of amyloid $\beta$ (A $\beta$ ) deposits, intracellular neurofibrillary tangles consisting of tau, and synaptic/neuronal loss (Price and Sisodia, 1998). The amyloid hypothesis states that $\mathrm{A} \beta$, especially $\mathrm{A} \beta_{1-42}$, is toxic to cells and is therefore the initiator for $\mathrm{AD}$ pathology (Price and Sisodia, 1998). Recently, a modified amyloid hypothesis, the so called "intracellular amyloid hypothesis," appeared (Li et al., 2007), which states that intracellular $\mathrm{A} \beta(\mathrm{iA} \beta)$ accumulation is the early event in AD development (Li et al., 2007). A strong piece of direct evidence for iA $\beta$ cytotoxicity comes from an experiment where microinjection of $\mathrm{A} \beta_{1-42}$ induces significant cell death in human primary cultured neurons (Zhang et al., 2002). Since iA $\beta$ effectively causes cell death in neurons and could be one of the primary events of AD development (Zhang et al., 2002), in the present study, iA $\beta$ was used as an inducer of cytotoxicity in neurons. The purpose of this study is to determine whether morphine plays a neuroprotective role against iA $\beta$ toxicity, and 
therefore whether it could have the potential as an $\mathrm{AD}$ prevention or treatment. We find that morphine, as well as endomorphin-1 (EM-1) and endomorphin-2 (EM-2), can protect against iA $\beta$ toxicity in human neuronal and rat hippocampal neuronal primary cultures and in rat brain in vivo. Furthermore, we investigate how morphine protection is mediated. Our data show that morphine induces estrogen release from local hippocampal neurons, possibly by increasing $\mathrm{P} 450$ aromatase activity. Increased estrogen triggers upregulation of heat shock protein 70 (Hsp70). Hsp70 protects against iA $\beta$ toxicity by increasing proteasomal activity, which is reduced by iA $\beta$.

\section{Materials and Methods}

Chemicals, peptides, recombinant proteins, cDNA constructs, siRNAs, and antibodies

Morphine hydrochloride (China Drug Regulation Bureau, Beijing, China), EM-1 (Tocris Bioscience), EM-2 (Tocris Bioscience), naloxone (Tocris Bioscience), naltrindole (Tocris Bioscience), $\beta$-funaltrexamine ( $\beta$-FNA; Tocris Bioscience), nor-binaltorphimine (nor-BNI; Tocris Bioscience), tamoxifen (Tax; Sigma), phenol red (Sigma), lipofectamine 2000 (Invitrogen), staurosporine (STS; Sigma), etoposide (Etop; Sigma), glutamate (Glu; Sigma), kainic acid (KA; Sigma), $\mathrm{H}_{2} \mathrm{O}_{2}$ (Beijing Chemicals), TNF- $\alpha$ (Sigma), tunicamycin (Tocris Bioscience), thapsigargin (Tocris Bioscience), phorbol esters (Sigma), PKA inhibitor fragment (622; Tocris Bioscience), bovine serum albumin (BSA)-conjugated morphine (BAS-M; a kind gift from Dr. Z. Gong, Institute for Military Medical Sciences, Beijing, China), $17-\beta$-estradiol ( $\beta \mathrm{E}_{2}$; Sigma), MG-132, a potent and cell permeable proteasome inhibitor (Sigma), lactacystein (Promega), and Z-VEID-fmk (CalBiochem) were used in the experiments. $\mathrm{A} \beta_{1-42}$ and the reversed control $\mathrm{A} \beta_{42-1}$ peptides (Bachem) were dissolved in sterile distilled water at $25 \mu \mathrm{M}$ and immediately frozen at $-20^{\circ} \mathrm{C}$. Recombinant Hsp70 (Calbiochem), caspase-6 (Calbiochem), and BSA (Sigma) were used for microinjection. The cDNA constructs of pCep $4 \beta$-cA $\beta_{1-42}$ expressing intracellularly located $\mathrm{A} \beta_{1-42}$ (Zhang et al., 2002), pCep $4 \beta$-sA $\beta_{1-42}$ expressing secreted $A \beta_{1-42}$ (Zhang et al., 2002), wild-type (WT) estrogen receptor (ER) (Zhang et al., 2004), ER with deletion of its DNA binding domain (ERADBD) (Zhang et al., 2004), wild-type androgen receptor (AR) (Zhang et al., 2004), 15579 (Zhang et al., 2004), 12474 (Zhang et al., 2004), wild-type p53 (Zhang et al., 2002), p53 dominant negative (Zhang et al., 2002), Bcl2 (Zhang et al., 2002), PKA dominant-negative construct (PKAI) (Day et al., 1989), mutant PKAI (PKAIM) (Day et al., 1989), and EGFP-fused ubiquitin (Ub-EGFP; a kind gift from Dr. R. Vabulas, Max Planck Institute of Biochemistry, Martinsried, Germany) were diluted with PBS before microinjection at $30 \mu \mathrm{g} / \mathrm{ml}$. All siRNAs and controls (Qiagen) were diluted into $5 \mathrm{~nm}$ before injection or transfection by HiPerFect (Qiagen) as described by the manufacturer. The silencing efficiency and off-target effects of all siRNAs were verified by Qiagen. Antibodies to Hsp70 (Stressgen), Hsc70 (Stressgen), activated-Bax 6A7 (R \& D Systems), actin (Santa Cruz Biotechnology), ER $\alpha$ (Santa Cruz Biotechnology), $\beta \mathrm{E}_{2}$ (Santa Cruz Biotechnology), morphine (Santa Cruz Biotechnology), $\mu$-opioid receptor (MOR; Santa Cruz Biotechnology), A $\beta$ 6E10 (Signet), and control IgG rabbit serum (Sigma) were used for Western blot, immunostaining, medium absorption, and microinjection. For medium absorption, precleaned protein-A Sepharose beads (Sigma) were coated with antibodies for overnight at $4^{\circ} \mathrm{C}$ and used for absorption of conditioned medium. $\beta$ Secretase Activity Assay Kit (Abcam; Ab65357) and $\gamma$-Secretase Activity Kit (R \& D Systems; FP003) were used to measure $\beta$ - and $\gamma$-secretase activities as described by the manufacturer.

\section{Cell culture}

Primary cultures of human neurons were prepared from 8- to 12-weekold fetal brains following the protocol approved by the Peking University Medical School Institutional Review Board (IRB00001052-0572). Rat primary neurons were cultured from newborn Sprague Dawley rat hippocampus, and mouse primary neurons were cultured from the hippocampus in newborn mice indicated, following the regulations of Peking University Animal Care and Use Committee. In brief, fresh fetal whole-brain or rat hippocampal tissues were dissociated with $0.25 \%$ trypsin (Invitrogen), which was then inactivated by $10 \%$ decomplemented fetal bovine serum (FBS; HyClone). The mixture was triturated through pipette to make a homogenous mixture. After filtering the mixture through $70 \mu \mathrm{m}$ sterilized filters, the flow-through was centrifuged. The pellet was then washed once with PBS and once with DMEM containing $0.225 \%$ sodium bicarbonate, $1 \mathrm{~mm}$ sodium pyruvate, $2 \mathrm{~mm}$ L-glutamine, $0.1 \%$ dextrose, and $1 \times$ antibiotic Pen-Strep (all from Invitrogen) with 5\% FBS. Cells were then plated on poly-L-lysine-coated (Sigma) plates or glass coverslips at a density of $3 \times 10^{6}$ cells $/ \mathrm{ml}$. Neurons were incubated at $37^{\circ} \mathrm{C}$ in DMEM without phenol red with 5\% FBS and with $5 \%$ circulating $\mathrm{CO}_{2}$. Cytarabine was added to culture media $24 \mathrm{~h}$ after plating at $10 \mu \mathrm{M}$ to inhibit cell growth. Medium was changed every $48 \mathrm{~h}$. Cells were treated for experiments at $7 \mathrm{~d}$ in culture. MCF-7 and MDA-MB231 cells (a kind gift from Dr. Y. Shang, School of Medicine, Peking University, Beijing, China) were maintained in RPMI 1640 medium (Invitrogen). For morphine, EM-1 and EM-2 treatment in neuronal culture, chemicals were diluted from the stock solutions into indicated concentrations with culture medium, added to the culture, and incubated for the indicated time at $37^{\circ} \mathrm{C}$.

\section{Microinjection}

Thin-walled borosilicate glass capillaries (outer diameter, $1.0 \mathrm{~mm}$; inner diameter, $0.5 \mathrm{~mm}$ ) with microfilament (MTW100F-4; World Precision Instruments) were pulled with a Flaming-Brown micropipette puller (P-97; Sutter Instrument) to obtain injection needles with a tip diameter of $\sim 0.5 \mu \mathrm{m}$. Microinjections were performed in the cytosol of each cell using the Eppendorf Microinjector FemtoJet and Eppendorf Micromanipulator. Neurons were injected with $25 \mathrm{fl}$ per shot at an injection pressure of $100 \mathrm{hPa}$, a compensation pressure of $50 \mathrm{hPa}$, and an injection time of $0.1 \mathrm{~s}$. A $\beta$ peptides were diluted with PBS $(0.14 \mathrm{M} \mathrm{NaCl}, 0.003 \mathrm{M} \mathrm{KCl}$, $0.01 \mathrm{M} \mathrm{Na}_{2} \mathrm{HPO}_{4}, 0.002 \mathrm{M} \mathrm{KH}_{2} \mathrm{PO}_{4}, \mathrm{pH} 7.2$ ) before microinjection at 10 nM. Recombinant Hsp70, caspase-6, and BSA were injected at $5 \mu \mathrm{g} / \mathrm{ml}$. The solutions were injected at the indicated concentrations with 100 $\mu \mathrm{g} / \mathrm{ml}$ dextran Texas Red (DTR; molecular weight, 3000; Invitrogen) as a fluorescent marker to recognize the injected cells. Approximately $90 \%$ of neurons survived the injections for at least $16 \mathrm{~d}$ (LeBlanc, 1995).

\section{Adenovirus infection}

Intracellular $\mathrm{A} \beta_{1-42} \mathrm{CDNA}$ was subcloned from pEGFP-N3 into pAdTrack with BglII and XhoI digestions. Adenovirus was packaged in HEK293 cells, and the infectious particle was measured as $2 \times 10^{6}$ particles $/ \mathrm{ml}$ (multiplicity of infection, 1.33). To infection of cell cultures, the purified virus supernatant was added to cell culture medium at a dilution of 1:500 for $24 \mathrm{~h}$.

\section{Electrophysiology}

Whole-cell voltage-clamp recordings were performed on cultured hippocampal neurons. An Axopatch 200B amplifier (Molecular Devices) was used for whole-cell patch clamp. Before electrophysiological recording, culture medium was replaced with a bath solution containing the following (in mM): $141 \mathrm{NaCl}, 2.5 \mathrm{KCl}, 1.3 \mathrm{MgCl}_{2}, 2.4 \mathrm{CaCl}_{2}, 1.25$ $\mathrm{NaH}_{2} \mathrm{PO}_{4}, 10$ HEPES, and $11 \mathrm{D}$-glucose (all from Sigma; $\mathrm{pH}$ 7.35). To block voltage-dependent $\mathrm{Na}^{+}$and $\mathrm{Ca}^{2+}$ currents, $1 \mu \mathrm{M}$ TTX (Fishes Research Institute, Hebei, China) and $100 \mu \mathrm{M} \mathrm{CdCl}_{2}$ (Sigma) were added to bath solution. Patch pipettes were pulled on a P97 Flaming-Brown micropipettes puller. Pipettes had a resistance of 3-5 M $\Omega$. The electrodes were filled with the following (in $\mathrm{mm}$ ): $115 \mathrm{~K}$-gluconate, $5 \mathrm{KCl}, 2.5$ $\mathrm{MgCl}_{2}, 1 \mathrm{CaCl}_{2}, 10$ EGTA, $5 \mathrm{Na}_{2}$-ATP, and 10 HEPES (all from Sigma; $\mathrm{pH}$ 7.25). The neurons were held at $-70 \mathrm{mV}$ and then depolarized from -60 to $80 \mathrm{mV}$ with $10 \mathrm{mV}$ steps, and each pulse lasted for $500 \mathrm{~ms}$ (Hou et al., 2009). For $I_{\mathrm{A}}$ current isolation, neurons were first held at $-40 \mathrm{mV}$ to completely inactivate $I_{\mathrm{A}}$ and then depolarized from -60 to $80 \mathrm{mV}$ as before. Then the currents were recorded and subtracted from those evoked from the $-100 \mathrm{mV}$ holding potential using Clampfit 8.0 (Molecular Devices).

\section{Morris water maze}

Animal treatments. Male Sprague Dawley rats ( $\sim 250$ g of body weight $)$ or wild-type and APP/PS1 mice ( $\sim 30 \mathrm{~g}$ of body weight) were used in water maze experiments. Rats and mice were housed under constant tempera- 
ture and humidity conditions on a $12 \mathrm{~h}$ light/dark cycle with food and water available. Rats were randomly divided into six groups: $\mathrm{PBS}, \mathrm{pH}$ 7.4, treatment group; morphine $(1.2 \mu \mathrm{l} ; 500 \mu \mathrm{M})$ treatment group; $\mathrm{A} \beta(1 \mu \mathrm{l}$ of iA $\beta$-expressing virus in $0.2 \mu$ l of PBS) treatment group; EGFP ( $1 \mu \mathrm{l}$ of EGFP-expressing virus in $0.2 \mu$ of PBS) treatment group; $\mathrm{A} \beta$ plus morphine ( $1 \mu \mathrm{l}$ of iA $\beta$-expressing virus and $0.2 \mu \mathrm{l}$ of $3 \mathrm{~mm}$ morphine) cotreatment group; and EGFP plus morphine $(1 \mu \mathrm{l}$ of EGFP-expressing virus and $0.2 \mu \mathrm{l}$ of $3 \mathrm{~mm}$ morphine) cotreatment group. Mice were divided into four groups: wild type, APP/PS1, wild type with morphine treatment $(1.2 \mu \mathrm{l} ; 500 \mu \mathrm{M})$, and APP/PS1 with morphine treatment (1.2 $\mu \mathrm{l} ; 500 \mu \mathrm{M})$. Solution $(1.2 \mu \mathrm{l})$ was injected into each hippocampus over a 2 min period through a Hamilton microsyringe, and the needle was left in place for additional $3 \mathrm{~min}$. Injections were performed for 3 successive days.

Water maze tests. The Morris water maze apparatus consisted of a circular swimming pool measuring $120 \mathrm{~cm}$ in diameter and $50 \mathrm{~cm}$ in height for rats and $60 \mathrm{~cm}$ in diameter and $50 \mathrm{~cm}$ in height for mice. It was placed in a room where many extramaze cues were available on the walls. The pool was filled to a depth of $30 \mathrm{~cm}$ with $21-22^{\circ} \mathrm{C}$ water. The hidden platform top was a circular plate measuring $10 \mathrm{~cm}$ in diameter. The hidden platform was located $2 \mathrm{~cm}$ below the water surface. On the second day, rats/mice were trained to escape onto the hidden platform in the water maze. The pool was conceptually divided into four quadrants with equal area size. The hidden platform was placed in the center of one of the quadrants throughout the experiment. Each of the four cardinal points of perimeter of the pool was used randomly as a starting location. Before the experiment, the times rats spent in each quadrant (including the target quadrant) without the platform placed were recorded. A trial began when a rat/mouse was placed in the pool facing the wall and ended when the rat escaped onto the platform. The escape latency to the platform was recorded. If a rat failed to escape within $60 \mathrm{~s}$, the trial was terminated, the escape latency was defined as $60 \mathrm{~s}$, and the rat was guided to the platform by the experimenter. Rats/mice were given four trials per day for 5 consecutive days (total of 20 trials). On the sixth day, a probe trial test was performed by recording the times spent in each quadrant without a platform.

\section{Immunocytochemistry}

Cells were permeabilized in PBS-Triton X-100 at $4^{\circ} \mathrm{C}$, blocked with $10 \%$ donkey serum at room temperature, and incubated with anti-activated Bax antibody 6A7 (1:200) or anti-MOR (1:500) at $4^{\circ} \mathrm{C}$ for $24 \mathrm{~h}$. Cy2 or Cy3-conjugated donkey anti-rabbit antibody was applied as the secondary antibody. The nuclei were then staining by Hoechst $33258(1 \mu \mathrm{g} / \mathrm{ml}$; Sigma) for $15 \mathrm{~min}$ in dark. The coverslips were mounted with Immunon mounting medium (Shandon) onto glass slides. The results were analyzed by using fluorescence microscope (Olympus BH2-RFCA) with a digital camera (Olympus DP70 digital microscope camera).

\section{Liquid chromatography-mass spectrometry}

$17-\alpha$-Estradiol $\left(\alpha \mathrm{E}_{2}\right)$ was purchased from Sigma. Estrone $\left(\mathrm{E}_{1}\right), \beta \mathrm{E}_{2}$, estriol $\left(E_{3}\right), \beta E_{2}-d_{3}$, and $E_{1}-d_{2}$ were purchased as powders from Wako. Methanol, acetonitrile, ethyl acetate, hexane, and dichloromethane (all at HPLC grade) were purchased from Fisher Chemical. HPLC-grade water was prepared using a Milli-Q RC apparatus (Millipore). All analytes were extracted simultaneously using one Oasis hydrophilic-lipophilicbalanced (HLB) cartridge ( $6 \mathrm{ml}, 500 \mathrm{mg}$; Waters). The cartridge was preconditioned with $6 \mathrm{ml}$ of ethyl acetate, $6 \mathrm{ml}$ of acetonitrile, and $12 \mathrm{ml}$ of distilled water. The cytolymph samples $(\sim 50 \mathrm{ml})$ spiked with $10 \mathrm{ng}$ of all surrogate standards $\left(E_{1}-d_{2}\right.$ and $\left.\beta E_{2}-d_{3}\right)$ were extracted through the HLB cartridges at a flow rate of $5-10 \mathrm{ml} / \mathrm{min}$. The cartridges were rinsed with $10 \mathrm{ml}$ of distilled water and then dried under a flow of nitrogen. All analytes were subsequently eluted with $15 \mathrm{ml}$ of ethyl acetate and $6 \mathrm{ml}$ of ethyl acetate/acetonitrile $(1: 1, \mathrm{v} / \mathrm{v})$. The extracts were dried and redissolved in $0.2 \mathrm{ml}$ of ethyl acetate and $1.8 \mathrm{ml}$ of hexane. The mixed solutions were applied to silica cartridges $(3 \mathrm{ml}, 500 \mathrm{mg}$; Waters) that had been preconditioned with $4 \mathrm{ml}$ water-saturated ethyl acetate and $4 \mathrm{ml}$ hexane/ethyl acetate $(90: 10, \mathrm{v} / \mathrm{v})$. After the cartridges were rinsed with 3 $\mathrm{ml}$ of hexane/ethyl acetate $(90: 10, \mathrm{v} / \mathrm{v})$, the fraction $\mathrm{F} 1$ containing $\mathrm{E}_{1}$, $\alpha \mathrm{E}_{2}$, and $\beta \mathrm{E}_{2}$ were eluted with $3 \mathrm{ml}$ of hexane/ethyl acetate $(38: 62, \mathrm{v} / \mathrm{v})$,
Table 1. The separation conditions and maximize sensitivity of detection of the target compounds

\begin{tabular}{lllll}
\hline Compound & $\begin{array}{l}\text { Retention } \\
\text { time }(\mathrm{min})\end{array}$ & $\begin{array}{l}\text { Multiple reaction } \\
\text { monitoring transition }\end{array}$ & $\begin{array}{l}\text { Cone } \\
\text { voltage }(\mathrm{V})\end{array}$ & $\begin{array}{l}\text { Collision } \\
\text { energy }(\mathrm{eV})\end{array}$ \\
\hline Estrone $\left(\mathrm{E}_{1}\right)$ & 4.06 & $\begin{array}{l}269>145 \\
269>159\end{array}$ & 60 & 40 \\
& & $271>147$ & 56 & 36 \\
Estrone-d2 $\left(\mathrm{E}_{1}-\mathrm{d}_{2}\right)$ & 4.05 & $271>145$ & 60 & 38 \\
$17-\alpha$-Estradiol $\left(\alpha \mathrm{E}_{2}\right)$ & 3.89 & $271>183$ & & 42 \\
& & $271>145$ & 60 & 48 \\
$17-\beta$-Estradiol $\left(\beta \mathrm{E}_{2}\right)$ & 3.71 & $271>183$ & & 38 \\
& & $274>185$ & 58 & 46 \\
$17-\beta$-Estradiol-d3 $\left(\beta \mathrm{E}_{2}-\mathrm{d}_{3}\right)$ & 3.69 & $287>145$ & 60 & 40 \\
Estriol $\left(\mathrm{E}_{3}\right)$ & 2.45 & $287>171$ & & 34 \\
& & & & \\
\hline
\end{tabular}

and the fraction $\mathrm{F} 2$ containing $\mathrm{E}_{3}$ were subsequently eluted by $3 \mathrm{ml}$ of water-saturated ethyl acetate. F2 eluates were dried and reconstituted with $0.5 \mathrm{ml}$ of acetonitrile for $\mathrm{E}_{3}$ by liquid chromatography-electrospray ionization tandem mass spectrometry (LC-ESI-MS/MS). To analyze the estrogens except $\mathrm{E}_{3}, \mathrm{~F} 1$ was dried and redissolved with $1 \mathrm{ml}$ hexanemethylene chloride (DCM; $1: 1, \mathrm{v} / \mathrm{v}$ ), and then passed through the preconditioned Florisil cartridges $(6 \mathrm{ml}, 1 \mathrm{~g}$; Waters). Ten milliliters of a mixture of DCM $(1: 1, \mathrm{v} / \mathrm{v})$ were discarded, and the fraction containing $\mathrm{E}_{1}, \alpha \mathrm{E}_{2}$, and $\beta \mathrm{E}_{2}$ was eluted with $6 \mathrm{ml}$ of acetone-DCM (1:9, v/v). The solution was evaporated to dryness under a gentle stream of nitrogen and reconstituted with $0.5 \mathrm{ml}$ of acetonitrile.

The LC apparatus was an ACQUITY UPLC (Waters). All analytes were separated using a Waters ACQUITY UPLC BEH C18 column $(2.1 \times 100$ $\mathrm{mm}$; particle size, $1.7 \mu \mathrm{m}$ ). The column was maintained at $40^{\circ} \mathrm{C}$ at a flow rate of $0.3 \mathrm{ml} / \mathrm{min}$, and the injection volume was $5 \mu \mathrm{l}$. Acetonitrile (A) and water $(\mathrm{B})$ were used for analyzing estrogens. The gradient condition was initiated with $20 \%$ (A) followed by a linear increase to $100 \%$ (A) in $6.0 \mathrm{~min}$, and was held at $100 \%$ for $1.0 \mathrm{~min}$, and then decreased to the initial composition in $0.1 \mathrm{~min}$. The column was then equilibrated for 3.0 min. Mass spectrometry was performed using a Quattro Premier XE detector (Waters), which was operated with ESI in the negative ion mode. The detection conditions of the mass spectrometer were as follows: capillary voltage, $2.8 \mathrm{kV}$; source temperature, $110^{\circ} \mathrm{C}$; desolvation temperature, $400^{\circ} \mathrm{C}$; desolvation gas flow, $800 \mathrm{l} / \mathrm{h}$; and cone gas flow, $50 \mathrm{l} / \mathrm{h}$. Finally, data acquisition was performed under time-segmented conditions based on the chromatographic separation of the target compounds to maximize sensitivity of detection (Table 1). Identification of the target estrogens was accomplished by comparing the retention time (within $2 \%$ ) and the ratio (within 20\%) of the two selected precursor ion-production with those of standards. To automatically correct the losses of analytes during sample preparation and the matrix-induced change in ionization, and to compensate for variations in instrument response from injection to injection, $\mathrm{E}_{1}-\mathrm{d}_{2}$ was used as a surrogate standard for $\mathrm{E}_{1}$, and $\beta \mathrm{E}_{2}-\mathrm{d}_{3}$ was used for $\alpha \mathrm{E}_{2}, \beta \mathrm{E}_{2}$ and $\mathrm{E}_{3}$. The limits of detection of $\mathrm{E}_{1}, \alpha \mathrm{E}_{2}, \beta \mathrm{E}_{2}$, and $\mathrm{E}_{3}$ were $2.5,1.5,6$, and $3 \mathrm{pg} / \mathrm{ml}$, respectively.

\section{Measurement of neuronal cell death}

Cells were fixed in fresh $4 \%$ paraformaldehyde and $4 \%$ sucrose in PBS for $20 \mathrm{~min}$ at room temperature and permeabilized in $0.1 \%$ Triton X-100 and $0.1 \%$ sodium citrate in PBS for 2 min on ice. Terminal deoxynucleotidyl transferase-biotin dUTP nick-end labeling (TUNEL) staining was performed using the in situ cell death detection kit I as described by the manufacturer (Roche). The coverslips were then washed once in distilled water for $5 \mathrm{~min}$ and mounted on glass slides to be observed under a fluorescence microscope. For the noninjected cells, the percentage of cell death was determined by the ratio of the number of TUNEL-positive cells over the total of 100 cells in one count. The average of five counts was calculated as the percentage of neuronal cell death in a certain treatment. For the injected cells, the percentage of cell death was determined as the ratio of the number of DTR-TUNEL-double-positive cells over the total number of DTR-positive cells. For the infected tissue, the percentage of cell death was determined by the ratio of the number of TUNEL-positive cells over 100 EGFP-positive cells. 
A

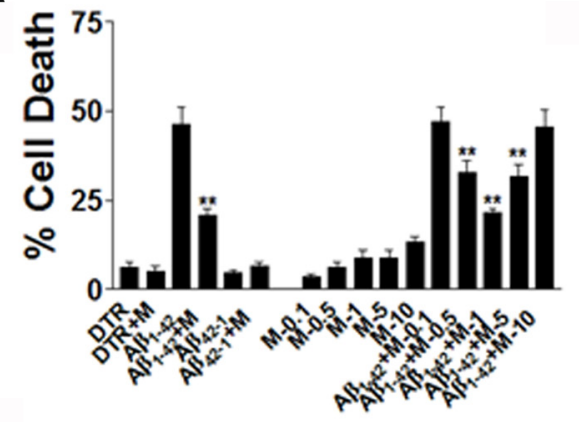

B

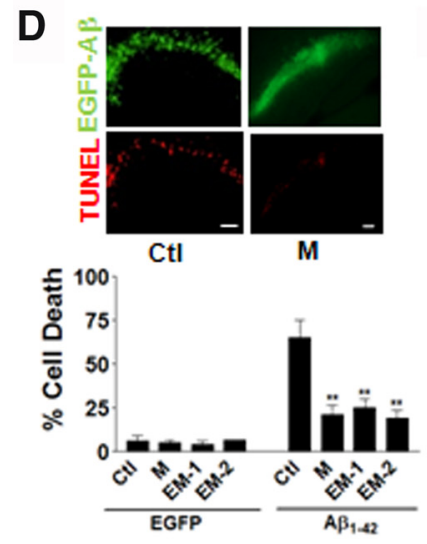

E EGFP Activated Bax
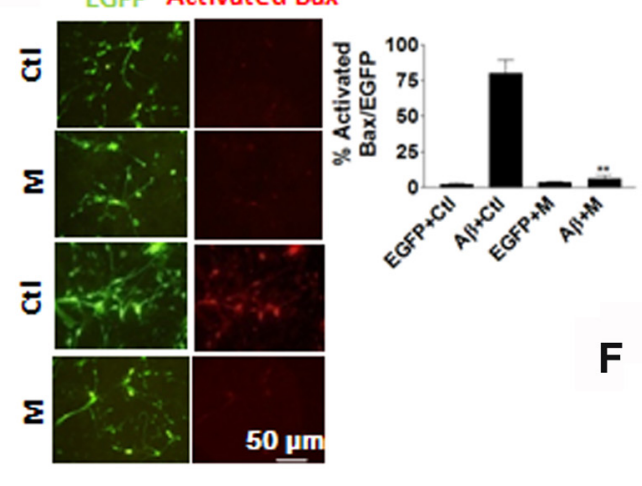

$\mathbf{F}$
C

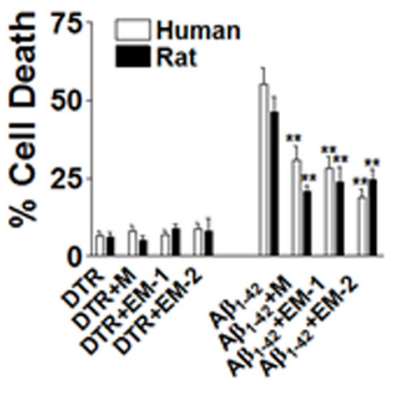

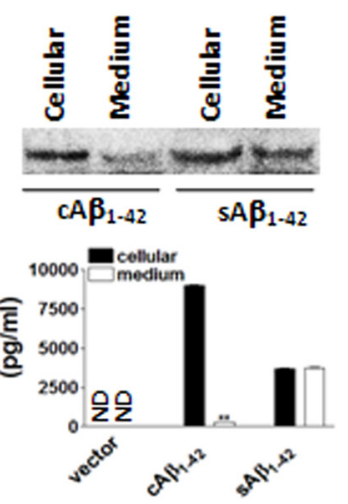
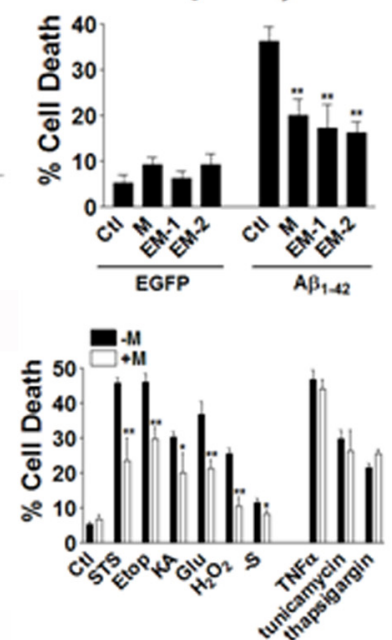

G
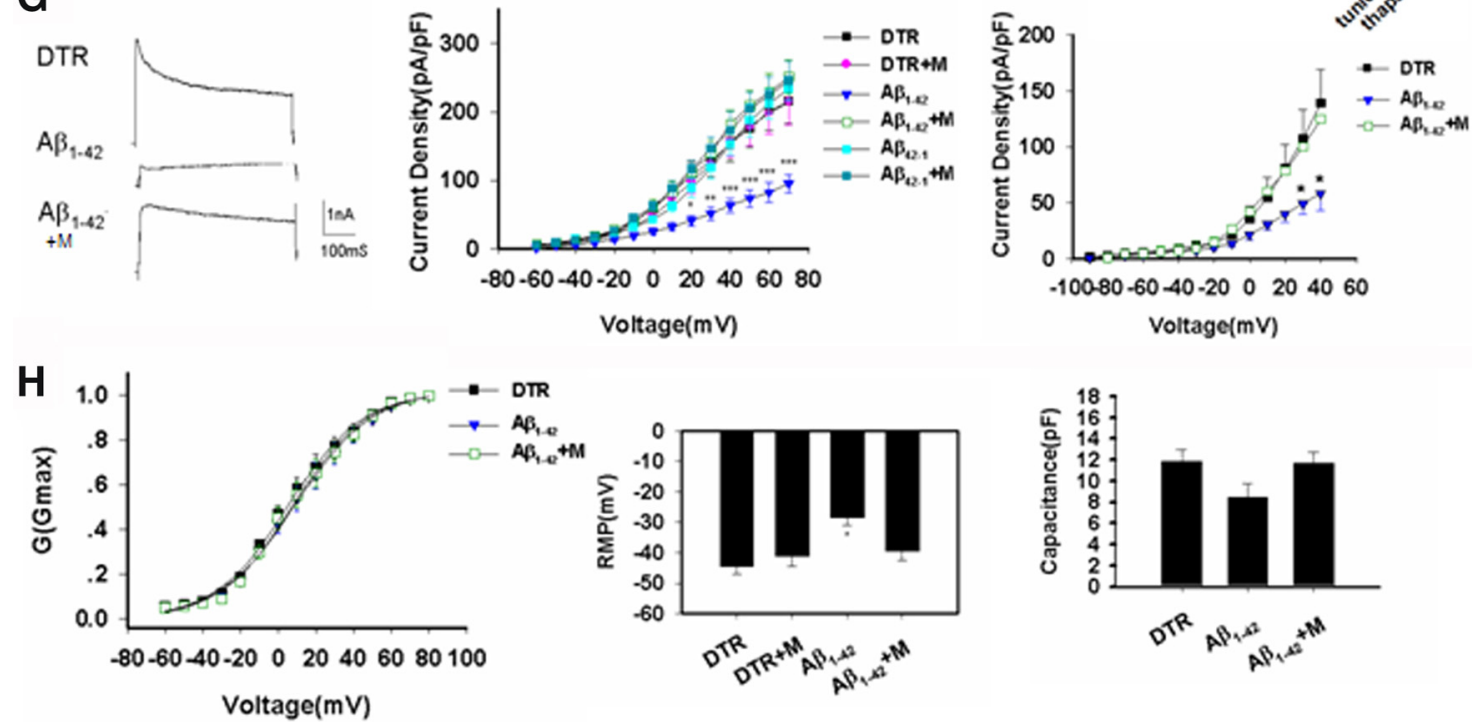

Figure 1. Morphine, endomorphin-1, and endomorphin-2 reduced cytotoxicity caused by intracellular $A \beta . A$, In cultured rat hippocampal neurons, cells were microinjected with $A \beta_{1-42}$ or control reversed peptide $A \beta_{42-1}$. Different doses of morphine $(M)$ ranging from 0.1-10 $\mu$ m were added to cells injected with $A \beta_{1-42}$ (200 cells were injected for each treatment in each experiment, and every experiment was repeated 3 times in independent preparations). ${ }^{* *} p<0.01$ compared with the iA $\beta_{1-42}$ group. $\boldsymbol{B}$, Morphine, EM-1, and EM- 2 significantly reduced cell death induced by $\mathrm{i} A \beta_{1-42}$ microinjection at $24 \mathrm{~h}$ treatment in human whole-brain and rat hippocampal neuronal cultures in three independent preparations (200 cells were injected for each treatment in each experiment, and every experiment was repeated 3 times). ${ }^{* *} p<0.01$ compared with the iA $\beta_{1-42}$ group. $C$, Top, The construct $C A \beta_{1-42}$ expressed $A \beta$ mainly in the cytosol with very low level secreted to the culture medium when tested in (6 rat glioma cell line with the antibody (6E10) specific to human $A \beta$. In contrast, the sequence coding for $A \beta_{1-42}$ with an additional signal peptide $\left(\mathrm{s} A \beta_{1-42}\right)$ expressed $A \beta$ in the cytosol as well as that secreted into the medium. Middle, The ELISA data for human $A \beta$ confirmed that, in $C 6$ cells, $C A \beta_{1-42}$ expressed $A \beta$ mainly in the cytosol, whereas $5 A \beta_{1-42}$ in both the cytosol and secreted form. Bottom, In rat hippocampal neuronal cultures, neurons infected by EGFP-expressing or iA $\beta_{1-42}$-expressing Adeno-5 virus were treated with $M, E M-1$, or EM-2. M, EM-1, and EM-2 remarkably increased cell viability in $\mathrm{i} \beta_{1-42}$ group at $24 \mathrm{~h}$ (200 cells were counted for each treatment in each experiment, and every experiment was repeated 3 times). ${ }^{* *} p<0.01$ compared with $\mathrm{iA} \beta_{1-42}$ group. ND, Not detected. $\boldsymbol{D}$, Rat hippocampus CA1 areas were injected with EGFP-expressing or iA $\beta_{1-42}$-expressing Adeno-5 virus. Top, TUNEL-positive cells were less in the morphine-treated tissue than in the control tissue. Bottom, M, EM-1, and EM-2 greatly increased cell survival in iA $\beta_{1-42}$ group at $24 \mathrm{~h}$ ( 200 cells were counted for each treatment in each experiment, and every experiment was repeated 3 times). ${ }^{* *} p<0.01$ compared with iA $\beta_{1-42}$ group. $E$, Rat hippocampal neurons infected with EGFP-expressing or iA $\beta_{1-42}$-expressing Adeno- 5 virus stained with activated Bax. Morphine reduced the level of activated Bax to the control group level at $24 \mathrm{~h} \mathrm{(200} \mathrm{cells} \mathrm{were} \mathrm{counted} \mathrm{for} \mathrm{each} \mathrm{treatment} \mathrm{in} \mathrm{each} \mathrm{experiment,} \mathrm{and} \mathrm{every}$ experiment was repeated 3 times). ${ }^{* *} p<0.01$ compared with iA $\beta_{1-42}$ group. $\boldsymbol{F}$, Morphine reduced toxicities by STS, Etop, KA, Glu, $\mathrm{H}_{2} \mathrm{O}_{2}$, serum deprivation (-S), TNF- $\alpha$, tunicamycin, and thapsigargin in cultured rat hippocampal neurons at $24 \mathrm{~h}$ of treatment (200 cells were counted for each treatment in each experiment, and every experiment was repeated 3 times (Figure legend continues.) 


\section{Real-time PCR}

Cells were harvested and total RNA was isolated with TRIGene reagent (GenStar BioSolutions). Total RNA $(2 \mu \mathrm{g})$ was reverse transcribed using TransScript II First-Strand cDNA Synthesis SuperMix (Beijing TransGen Biotech). Real-time PCRs were done using TransStart Green qPCR SuperMix UDG (Beijing TransGen Biotech). Sequences of primers for the rat CYP19 (P450 cytochrome aromatase) used were as follows: forward, 5'-GCCTGTCGTGGACTTGGT-3'; reverse, 5' -TTCCGATGTTCAGAAT GATGTT- $3^{\prime}$. Sequences of primers for the rat $\beta$ amyloid cleaving enzyme (BACE)-1 used were as follows: forward, $5^{\prime}$-TTGCCCAAGAAAGTATTT GA-3'; reverse, 5'-GATGCGGAAGGACTGATT-3'. Sequences of primers for the rat BACE- 2 used were as follows: forward, $5^{\prime}$-AGGTAGTCTTGTCC TGGGTG-3'; reverse, 5' ${ }^{\prime}$-TGGCCTTGTCTGCGTTAT-3'. Real-time PCR quantifications were run in triplicate for each sample, and the average were determined. To use the comparative $\mathrm{Ct}$ method for relative quantification, the amplification efficiency of target and housekeeping genes must be approximately equal. Quantification was done using the comparative $\mathrm{Ct}$ method, and expression levels for the target gene were normalized to the GAPDH of each sample $\left(2^{-\triangle \mathrm{Ct}}=2^{-[\mathrm{Ct}(\text { target gene })-\mathrm{Ct}(\mathrm{GAPDH})]}\right)$. Amplification was done for 45 cycles at $95^{\circ} \mathrm{C}$ for $30 \mathrm{~s}, 59^{\circ} \mathrm{C}$ for $30 \mathrm{~s}, 72^{\circ} \mathrm{C}$ for $30 \mathrm{~s}, 95^{\circ} \mathrm{C}$ for $1 \mathrm{~min}, 59^{\circ} \mathrm{C}$ for $30 \mathrm{~s}$, and $95^{\circ} \mathrm{C}$ for $30 \mathrm{~s}$.

\section{ELISA}

ELISA was used to determine the concentrations of $\beta \mathrm{E} 2$ and testosterone in the culture medium and $\mathrm{A} \beta_{1-40}$ and $\mathrm{A} \beta_{1-42}$ in the hippocampal tissues of APP/PS1 mice. Conditioned culture medium was collected and kits for determine $\beta \mathrm{E}_{2}$ (Assay Designs) and testosterone (DIAsource ImmunoAssays) were used to measure their concentrations as described by the manufacturer. The kits for determining $\mathrm{A} \beta_{1-42}$ ( $\mathrm{R} \& \mathrm{D}$ Systems) were used as described by the manufacturer. Then the relative optical intensity of each well was read out by the microplate reader (Bio-Rad 480).

\section{Proteasomal activity assay}

Neuronal proteins were extracted in the cell lysis buffer $(50 \mathrm{~mm}$ Tris, $\mathrm{pH}$ 8.0, $150 \mathrm{~mm} \mathrm{NaCl}, 1 \% \mathrm{NP}-40,0.1 \%$ SDS) after treatments. Proteasomal activities were measured with cell extracts added by Proteasom-Glu Assay System (Promega) as described by the manufacturer.

\section{Western blots}

Neuronal proteins were extracted in the cell lysis buffer (50 mM Tris, $\mathrm{pH}$ 8.0, $150 \mathrm{~mm} \mathrm{NaCl}, 1 \% \mathrm{NP}-40,0.1 \%$ SDS), and protein concentrations were measured by bicinchoninic acid (BCA) assay (Pierce). Protein extracts were denatured at $100^{\circ} \mathrm{C}$ for 5 min and separated on $15 \%$ SDSPAGE at $70 \mathrm{~V}$ for $\sim 2 \mathrm{~h}$. Proteins were transferred to Immobilon-P polyvinylidene fluoride membrane (Millipore) at 100 milliamps for $2 \mathrm{~h}$. The membrane was blocked with $5 \%$ nonfat milk in Tris-buffered saline with $0.1 \%$ Tween 20 (TBS-T) at room temperature for $1 \mathrm{~h}$. Anti-Hsp70, anti-Hsc70, anti-MOR, anti-A $\beta 6 \mathrm{E} 10$, and anti-actin antibodies were diluted at 1:1000 for Western blots as primary antibodies. After 3 washes of $10 \mathrm{~min}$ each with TBS-T, goat anti-rabbit IgG conjugated

\section{$\leftarrow$}

(Figure legend continued.) in independent preparations). ${ }^{* *} p<0.01$ compared with the $-M$ group. G, Left, Typical traces recorded from control, $i A \beta_{1-42}$, and $i A \beta_{1-42}+M$ group of neurons after $24 \mathrm{~h}$ treatment. Calibration: $1 \mathrm{nA}, 100 \mathrm{~ms}$. Middle, Whole-cell $\mathrm{K}^{+}$current density recorded from different treatment groups at $24 \mathrm{~h}$ ( 10 cells were recorded for each treatment in each experiment, and every experiment was repeated 3 times in independent preparations). Right, A-type $\mathrm{K}^{+}$current density recorded from different treatment groups at $24 \mathrm{~h}$ (10 cells were recorded for each treatment in each experiment, and every experiment was repeated 3 times in independent preparations). ${ }^{*} p<0.05 ;{ }^{* *} p<0.01 ;{ }^{* * *} p<0.001$ compared with the control group. $\boldsymbol{H}$, Left, Activation curve of $\mathrm{K}^{+}$current at $24 \mathrm{~h}$. There was no difference between treatment groups (10 cells were recorded for each treatment in each experiment, and every experiment was repeated 3 times in independent preparations). Middle, $\mathrm{i} A \beta_{1-42}$ decreased the membrane capacitance of injected neurons at $24 \mathrm{~h}$, although the difference was not statistically significant $(p=0.06 ; n=3)$. Right, Resting membrane potentials recorded from different treatment groups at $24 \mathrm{~h}$ (10 cells were recorded for each treatment in each experiment, and every experiment was repeated 3 times in independent preparations). Scale bars: $\boldsymbol{D}, \boldsymbol{E}, 50 \mu \mathrm{m}$. Error bars indicate SEM. with horseradish peroxidase (HRP) was added in a dilution of 1:2500 as the secondary antibody. The secondary HRP was detected by enhanced chemiluminescence. Optical density was analyzed by Bio-Rad ChemiDox.

\section{Statistical evaluation}

Statistical significance was assessed by one-way ANOVA. Sheffé's test was applied as a post hoc test for the significant difference showed by ANOVAs. A $p$ value of $<0.05$ was used as an indicative of statistical significance. Power analysis for each experiment to validate group size was done using SPSS software, version 13.0.

\section{Results \\ Morphine, endomorphin-1, and endomorphin-2 reduced cytotoxicity caused by intracellular $\mathbf{A} \beta$}

To examine the protective effects of morphine, we determined whether morphine could be neuroprotective against iA $\beta$ toxicity in cultured cells. In rat hippocampal neuronal cultures, microinjected iA $\beta_{1-42}$ induced $\sim 50 \%$ cell death compared to injection marker dye DTR alone in $24 \mathrm{~h}$ after direct microinjection of peptides measured by TUNEL (Fig. $1 A$ ). In our previous study, the injected $\mathrm{iA} \beta_{1-42}$ contained monomeric, dimeric, trimeric, and high-molecular-weight fibrillar forms, while the toxic components were likely dimers, trimers, and fibrillars (Zhang et al., 2002). The injected $A \beta$ remained in the neurons for at least $4 \mathrm{~d}$, as indicated by the cytotoxicity data (Zhang et al., 2002). A $\beta$ toxicity reached a maximal plateau at $4 \mathrm{~d}$ and lasted for $16 \mathrm{~d}$ after injection (Zhang et al., 2002). Microinjection of control reversed peptide $\mathrm{A} \beta_{42-1}$ did not induce remarkable cell death. Morphine $(1 \mu \mathrm{M})$ had minimal effects on $\mathrm{A} \beta_{42-1}$ (Fig. 1A). To explore the dose effect of morphine, different dosages of morphine ranging from 0.1 to $10 \mu \mathrm{M}$ were added to neurons injected with $\mathrm{A} \beta_{1-42}$. Morphine, at $0.5,1$, and $5 \mu \mathrm{M}$, but not at $10 \mu \mathrm{M}$, blocked $\mathrm{A} \beta$-induced cell death (Fig. 1A). Since $1 \mu \mathrm{M}$ morphine gave the maximal protective effect (Fig. $1 A$ ), we used this dose for the later in vitro experiments. To compare the dosage we used in the present study to the levels of morphine in the serum in patients from clinics, literature reported that in the cancer patients with chronic pain, slow-release morphine was applied daily after an immediaterelease dose. Serum levels of morphine and its metabolites morphine-6-glucuronide and morphine-3-glucuronide were measured as 66, 257, and $1943 \mathrm{~nm}$, respectively. (Klepstad et al., 2000). In rat hippocampal and human neuronal cultures, morphine $(1 \mu \mathrm{M})$, as well as EM-1 $(1 \mu \mathrm{M})$ and EM-2 $(1 \mu \mathrm{M})$, reduced cell death caused by iA $\beta$ to $\sim 25 \%$ (Fig. $1 B$ ). To confirm the above protective effects of morphine, rat hippocampal neurons in culture were infected by Adeno- 5 virus containing intracellularly expressed $\mathrm{A} \beta_{1-42}$, which coded for the entire human $\mathrm{A} \beta_{1-42}$ sequence ( 42 amino acids) without any signal peptide (Zhang et al., 2002). As previously showed in human neurons (Hou et al., 2009 ), this construct ( $\left.\mathrm{cA} \beta_{1-42}\right)$ expressed $\mathrm{A} \beta$ mainly in the cytosol with very low level secreted to the culture medium (Fig. $1 C$, top panel) when tested in C6 rat glioma cell line with the antibody (6E10) specific to human $A \beta$. In contrast, the sequence coding for $A \beta_{1-42}$ with an additional signal peptide $\left(\mathrm{sA} \beta_{1-42}\right)$ expressed $\mathrm{A} \beta$ in the cytosol as well as secreted into the medium (Fig. $1 C$, top panel). The ELISA data for human A $\beta$ confirmed that, in C6 cells, $\mathrm{cA} \beta_{1-42}$ expressed $\mathrm{A} \beta$ mainly in the cytosol, whereas $\mathrm{sA} \beta_{1-42}$ in both the cytosol and secreted form (Fig. $1 C$, middle panel). The toxicity of $\mathrm{cA} \beta_{1-42}$ and $\mathrm{sA} \beta_{1-42}$ was examined in the previous study that, when microinjected, $\mathrm{cA} \beta_{1-42}$ induced much higher toxicity than $\mathrm{sA} \beta_{1-42}$ in human neurons (Zhang et al., 2002). Here, rat hippocampal neurons was infected with Adeno- 5 virus packaged with $\mathrm{cA} \beta_{1-42}$ constructs with or without treatments of 
morphine $(1 \mu \mathrm{M}), \mathrm{EM}-1$ (1 $\mu \mathrm{M})$ or EM-2 $(1 \mu \mathrm{M})$. Similar to observed with A $\beta$ peptide microinjection, $\mathrm{A} \beta$ induced $\sim 40 \%$ cell death at $24 \mathrm{~h}$ after infection, morphine, EM-1 and EM-2 protected such cell death by $\sim 50 \%$ (Fig. $1 C$ ).

To further confirm morphine protection in vivo, intracellularly expressed $\mathrm{A} \beta_{1-42}$ was packaged into Adeno-5 virus and infected to rat hippocampus CA1 area. iA $\beta_{1-42}$ induced $\sim 40 \%$ cell death compared to the vector control group containing only EGFP in the brain slices collected at $24 \mathrm{~h}$ after infection (Fig. $1 D$ ). The cell death was reduced to $\sim 20 \%$ by morphine, EM-1, and EM-2 (all at 500 $\mu \mathrm{M}, 1.2 \mu \mathrm{l}$; Fig. 1D). To indicate the types of cell death (apoptosis, necrosis, or autophagy), the proapoptotic proteinactivated Bax was also examined in virusinfected cultured rat hippocampal neurons. iA $\beta_{1-42}$ promoted a dramatic increase of activated Bax, which was reduced to control levels by morphine application ( $1 \mu \mathrm{M}$; Fig. $1 E)$. To further explore whether morphine protection was specific to iA $\beta_{1-42}$ toxicity, various insults were applied to cultured rat hippocampal neurons with or without the presence of morphine (Fig. $1 F$ ). The results indicated that morphine attenuated the toxicity induced by STS $(1 \mu \mathrm{M})$, Etop $(1 \mu \mathrm{M})$, $\mathrm{KA}(100 \mu \mathrm{M})$, Glu $(100 \mu \mathrm{M}), \mathrm{H}_{2} \mathrm{O}_{2}(200$ $\mu \mathrm{M})$, and serum deprivation, suggesting that the neuroprotective effect of morphine could be extended beyond the amyloid toxicity (Fig. $1 F$ ). In contrast, morphine did not reverse the toxicity induced by TNF- $\alpha$ $(100 \mu \mathrm{g} / \mathrm{L})$, tunicamycin $(100 \mu \mathrm{g} / \mathrm{L})$, and thapsigargin $(100 \mu \mathrm{M})$, suggesting that morphine protection was selective (Fig. $1 F$ ).

To test the electrophysiological properties of $A \beta$-treated neurons, $\mathrm{K}^{+}$currents were recorded from rat hippocampal neurons microinjected with $\mathrm{A} \beta_{1-42}$ or $\mathrm{A} \beta_{42-1}$ peptides with or without treatment of morphine (Fig. $1 G$, left). Our results suggested that $\mathrm{A} \beta_{1-42}$ reduced the whole-cell $\mathrm{K}^{+}$current density (Fig. $1 G$, left), consistent with the results reported previously (Good and Murphy, 1996; Hou et al., 2009). The voltage-dependent activation of $\mathrm{K}^{+}$currents showed no significant changes in $\mathrm{A} \beta_{1-42}$-injected neurons with or without morphine treatment (Fig. $1 G$, middle). Furthermore, the A-type $\mathrm{K}^{+}$current density of the $\mathrm{A} \beta_{1-42}$ injected cells was lower than that of the control group (Fig. 1G, right). Morphine treatment alone had no effect on the $\mathrm{K}^{+}$current density (Fig. 1G, middle). However, it blocked the reduction of both whole-cell and A-type $\mathrm{K}^{+}$current density induced by $\mathrm{A} \beta_{1-42}$ (Fig. $1 G$ ). Interestingly, there was a trend that $\mathrm{A} \beta_{1-42}$ decreased the membrane capacitance of injected neurons, although the difference was not statistically significant $(p=0.06)$. Morphine reversed the capacitance changes caused by $\mathrm{A} \beta_{1-42}$ (Fig. $1 \mathrm{H}$, middle). The resting membrane potentials of these treated neurons were also recorded. After $\mathrm{A} \beta_{1-42}$ treatment, the resting potential increased significantly $(-28.5 \pm 2.38 \mathrm{mV})$ compared with the control group $(-44.5 \pm 2.54 \mathrm{mV}$; Fig. $1 \mathrm{H}$, right $)$.
Morphine treatment rescued the membrane potential loss $(-39.5 \pm 3.04 \mathrm{mV}$; Fig. $1 \mathrm{H}$, right $)$.

To confirm morphine protective role in the spatial memory performance, the rats infected by virus packaged with iA $\beta_{1-42}$ in the hippocampus CA1 area in Morris water maze were tested. Instead of peripheral administration, morphine was injected into the hippocampus to ensure its protective effects were not secondary to effects induced by morphine to the peripheral systems. There were no significant differences in the time spent in the target quadrant before the training in various treatment groups (Fig. $2 A$, top left). iA $\beta_{1-42}$ increased the searching time to platform (Fig. $2 A$, top middle) and swimming distance of rats (Fig. $2 A$, top right), whereas morphine ( $500 \mu \mathrm{M}, 1.2 \mu \mathrm{l})$ reversed the changes induced by iA $\beta$ (Fig. $2 A$, top middle, top right). There was no significant difference in the swimming speed, suggesting that there was no difference in rat general locomotive ability (Fig. $2 A$, bottom left). After the test, with the platform removed, the probe trial data showed that iA $\beta$-infected rats spent significantly less time in the target quadrant than other groups of rats, and morphine injection reversed such effect (Fig. $2 \mathrm{~A}$, bottom right). The effects of morphine on spatial memory were also examined in the WT and APP/PS1 transgenic mice (Fig. 2B). Mice were examined at 6 months of age since APP/PS1 mice started to show 
abnormal LTP at $\sim 3$ months and cognitive impairment at 6 months (Trinchese et al., 2004). Also, APP/PS1 mice showed intracellular $\mathrm{A} \beta$ deposition at 2.5 months and dramatic extracellular A $\beta$ loads at 6 months (Blanchard et al., 2003). The similar improvement was observed in APP/PS1 mice performance with morphine treatment (Fig. $2 \mathrm{~B}$, top middle, top right, bottom right). The above results showed that morphine improved water maze test performance of rat infected with virus expressing intracellular $\mathrm{A} \beta$ or $\mathrm{APP} / \mathrm{PS} 1$ mice.

\section{Morphine protection was mediated through $\boldsymbol{\mu}$-opioid receptor and estrogen receptor activation}

We then explored the mechanisms of morphine protection against iA $\beta$ toxicity. There are three types of opioid receptors on rat hippocampal neuron surface, MOR, $\delta$-opioid receptor (DOR), and $\kappa$-opioid receptor (KOR) (Charron et al., 2008; Cui et al., 2008). To determine whether opioid receptors were involved in morphine protection against iA $\beta$ and which receptors played critical roles in its protection, pan opioid receptor antagonist naloxone $(1 \mu \mathrm{M})$ or antagonists to $\operatorname{MOR}(\beta$-FNA; $1 \mu \mathrm{M})$, DOR (naltrindole; $1 \mu \mathrm{M}$ ), and KOR (nor-BNI; $1 \mu \mathrm{M}$ ) were applied with morphine to the neurons microinjected with $\mathrm{A} \beta_{1-42}$ peptide. Naloxone and $\beta$-FNA blocked morphine protection, suggesting that MORs might be involved in morphine protection against iA $\beta$ (Fig. $3 A$ ). To further confirm that MORs played important role in morphine protection, two siRNAs to MOR were coinjected to neurons microinjected with $A \beta_{1-42}$ with or without treatment of morphine. The silencing efficiency and off-target effects of all siRNAs used in this study were verified by the manufacturer. While negative control siRNA did not alter morphine protection, two MOR siRNAs effectively reversed morphine protection, confirming that MORs were involved in morphine protection (Fig. 3B).

Estrogen and androgen were reported to effectively protect against iA $\beta$ toxicity in human neurons (Zhang et al., 2004). To investigate whether morphine protection was mediated by ERs, tamoxifen $(10 \mu \mathrm{M})$ was added to morphine treatment to $\mathrm{A} \beta_{1-42^{-}}$ injected neurons. Tax reduced morphine protection remarkably indicating that ERs might mediate morphine protection (Fig. 3C, top). Similarly, the involvement of MOR and ER was verified by naloxone and tamoxifen in the morphine protection against cytotoxicity induced by STS, Etop, KA, Glu, $\mathrm{H}_{2} \mathrm{O}_{2}$, and serum deprivation (Fig. $3 C$, bottom). To further confirm the involvement of ER, wild-type ER, ER $\triangle \mathrm{DBD}$, and siRNA to ER were coinjected with $\mathrm{A} \beta_{1-42}$ into neurons with the treatments of DMEM only, morphine, naloxone, morphine with naloxone, EM-1, and EM-2. Our data showed that depletions of ER function by ER $\triangle \mathrm{DBD}$ or siRNA greatly reversed morphine protection, confirming that ERs were the key players (Fig. 3D). Since data suggested that phenol red in culture medium can mimic weak estrogen (Berthois et al., 1986), DMEM with or without phenol red were tested for their effects on morphine protection. There was no significant difference between two kinds of media (Fig. $3 E$ ). To examine whether morphine induced ER activation, breast cancer cell lines MCF-7 (ER $\alpha$ positive) and MDA-MB231 (ER $\alpha$ negative) were used. MORs were expressed in both cell lines, demonstrated by immunostaining and Western blot with MOR antibody (Fig. 3F, left). Luciferase reporter assay for estrogen response element suggested that in MCF-7 cells, morphine induced ER activation to almost the same degree as its agonist $\beta \mathrm{E}_{2}$, whereas MCF-7 transfected with ER $\triangle \mathrm{DBD}$ or ER siRNA did not respond to morphine (Fig. $3 F$, right). ER $\alpha$-negative MDA-
MB231 cells only responded to morphine when they were transfected with wild-type ER (Fig. $3 F$, right).

\section{Morphine triggered estradiol release by neurons}

We further investigated how morphine activated ERs. There were several possible ways that morphine activates ERs: (1) morphine binds to membrane MOR, activating ER through the signaling pathway; (2) morphine, as a small molecule, might get into cell membrane and bind to ER directly; (3) morphine induces estradiol release, which then in turn activates ER. Morphine and estrogen action pathways might interact with each other through PKA or PKC (Wagner et al., 1998; Farooqui et al., 2006). When PKA was inhibited by either PKA inhibitor fragment (6-22), PKAI, or PKAIM microinjection, there was no significant effect on morphine protection (Fig. $4 A, B)$. PKC inhibitor STS $(0.5 \mu \mathrm{M})$ or PKC activator phorbol esters $(1 \mu \mathrm{M})$ did not alter morphine protection as well (Fig. $4 A, B$ ), suggesting that PKA or PKC might not be involved in morphine protection. To exclude the possibility that morphine could pass through cell plasma membrane, get into the cytosol area, and directly interact with cellular ER, BSA-M $(0.5 \mathrm{mg} / \mathrm{ml})$, which cannot pass through cell membrane, was added to $\mathrm{A} \beta_{1-42}$-injected neurons; BSA-M protected against iA $\beta_{1-42}$-induced cell death to almost the same extent as morphine, suggesting that morphine did not pass through cell membrane to have the protective effects (Fig. 4C).

Another possible way that morphine interacted with ER was to induce estradiol release by neurons. Neurons could produce estrogen by themselves (Zwain and Yen, 1999; Kim et al., 2000). The amounts of $\beta \mathrm{E}_{2}$, its metabolite estrone, and inactive $\alpha \mathrm{E}_{2}$ with or without morphine treatment were measured by LC-MS/MS. Our data showed that the levels of both $\beta \mathrm{E}_{2}$ and estrone remarkably increased in morphine-treated neurons, whereas $\alpha \mathrm{E}_{2}$ levels remained unchanged (Fig. $4 D$ ). Since in neurons, estrogens were produced from testosterone by $\mathrm{P} 450$ cytochrome aromatase (Lephart, 1996), the amount of testosterone was also measured by ELISA. Although ELISA data showed remarkable increase of $\beta \mathrm{E}_{2}$ levels in the morphine-treated group, there was no difference in testosterone between morphine-treated and control groups (Fig. $4 E$ ). The protective effects of morphine were also examined in the neurons microinjected with wild-type AR and two pointmutation-containing dominate-negative mutants, 15579 and 12474 (Zhang et al., 2004). Deletions of AR function by both 15579 and 12474 did not alter morphine protection, suggesting that testosterone and AR might not be involved in morphine protection (Fig. $4 F$ ).

Given that testosterone did not change with morphine treatment, the involvement of $\mathrm{P} 450$ cytochrome aromatase was tested by applying its siRNA. P450 cytochrome aromatase siRNA greatly reduced protection induced by morphine, EM-1, and EM-2, indicating that P450 cytochrome aromatase played an important role resulting in the increase of estrogen formation (Fig. $4 G$ ). There are two possible ways of increased P450 cytochrome aromatase function: (1) the expression level of P450 cytochrome aromatase might increase, or (2) if the amount of P450 cytochrome aromatase is constant, its activity might enhance. The level of P450 cytochrome aromatase was examined by realtime PCR, and the data showed that the levels of P450 cytochrome aromatase increased significantly at 2 and $4 \mathrm{~h}$ of morphine treatment, suggesting that morphine upregulated P450 cytochrome aromatase expression and therefore enhanced its activity (Fig. $4 H$ ). Since there was a study reporting that morphine could regulate BACE-1 and BACE-2 levels in neuroblastoma HTB-11 cells (Pak et al., 2005), we also examined the levels 
A

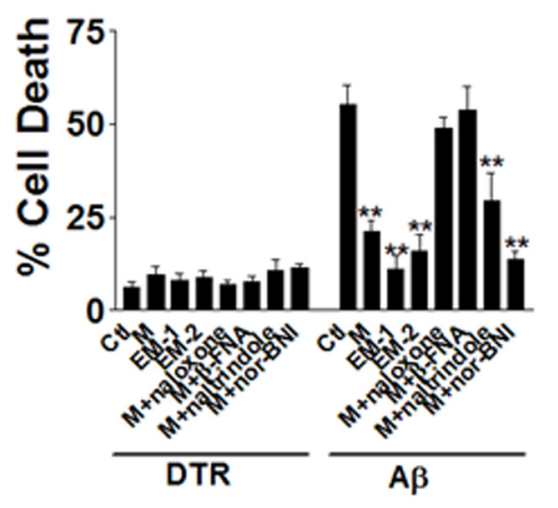

D
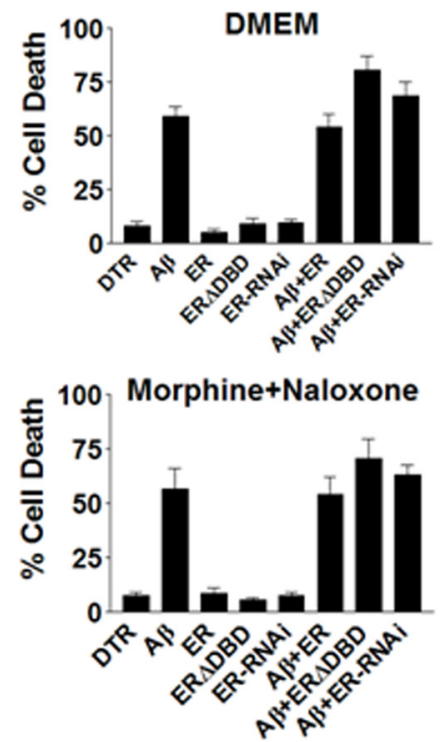

$\mathbf{E}$

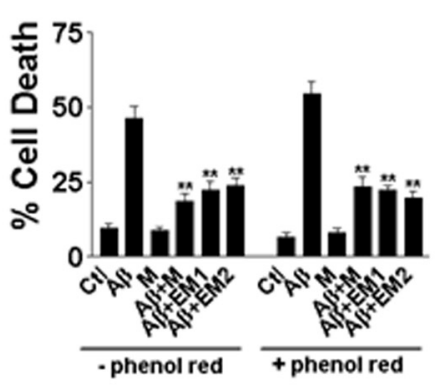

B

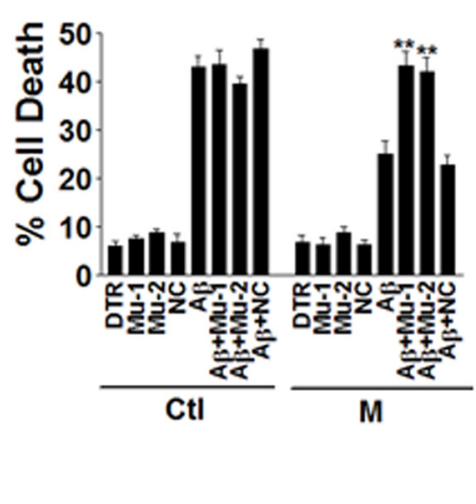

$C$

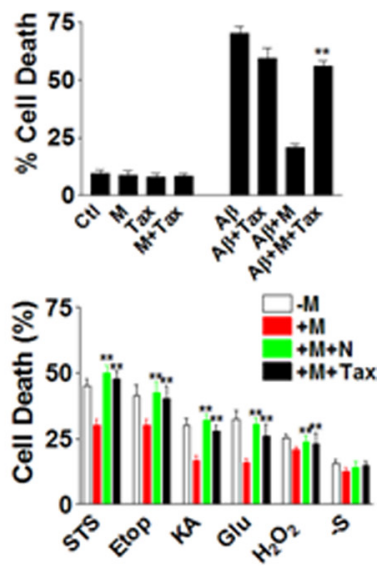

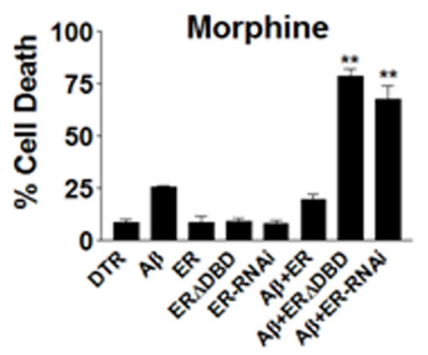

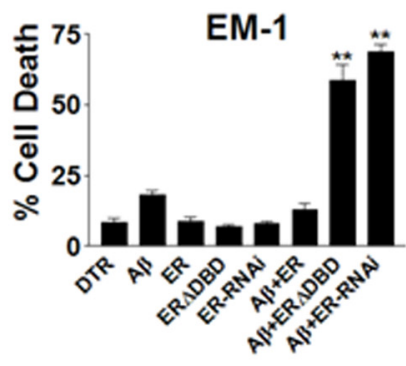

$\mathbf{F}$

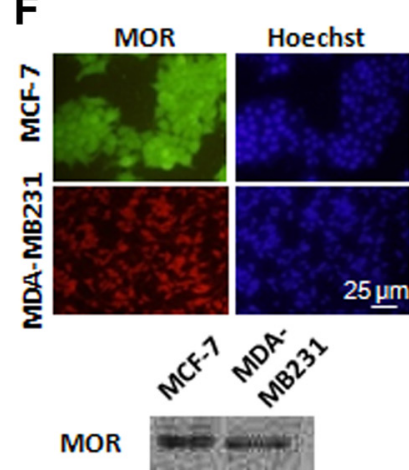

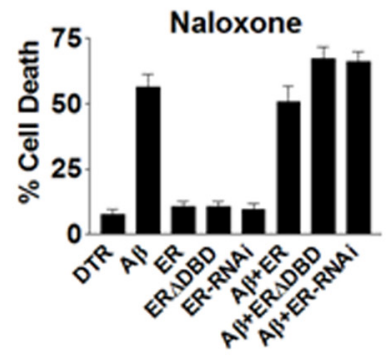

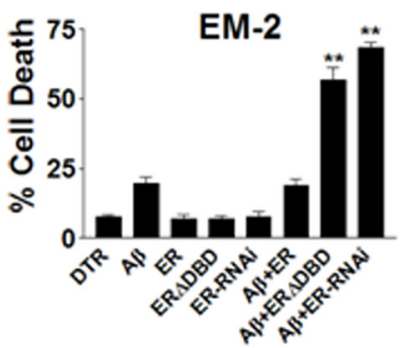

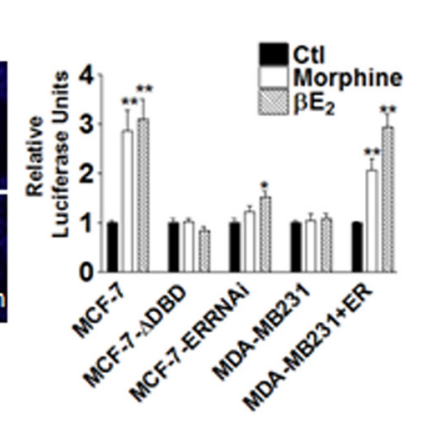

Figure 3. Morphine protection was mediated through $\mu$-opioid receptor and estrogen receptor activation. $A$, Naloxone, naltrindole, $\beta$-FNA, and nor-BNI treatments for $24 \mathrm{~h}$ suggested that MORs were involved in morphine protection (200 cells were injected for each treatment in each experiment, and every experiment was repeated 3 times). ${ }^{* *} p<0.01$ compared with the iA $\beta_{1-42}$ group. $\boldsymbol{B}$, Two siRNAs (Mu-1,Mu-2) and negative control siRNA were coinjected into neurons injected with iA $\beta_{1-42}$. Mu-1 and Mu-2 blocked morphine protection at $24 \mathrm{~h}$ (200 cells were injected for each treatmentin each experiment, and every experiment was repeated 3 times). ${ }^{* *} p<0.01$ compared with the iA $\beta_{1-42}+$ M group. $C$, Top, Tax blocked morphine protection (200 cells were injected for each treatment in each experiment, and every experiment was repeated 3 times). Bottom, Naxloxone and Tax reversed morphine protection (200 cells were counted for each treatment in each experiment, and every experiment was repeated 3 times). ${ }^{* *} p<0.01$ compared with the $\mathrm{A} A \beta_{1-42}+$ M group. $\boldsymbol{D}$, Wild-type ER, ER $\triangle D B D$, and siRNA to ER (ER-RNAi) were coinjected into neurons injected with A $\beta$. Neurons were then treated with DMEM, morphine, naloxone, morphine plus naloxone, EM-1, or EM-2 for $24 \mathrm{~h}$ (200 cells were injected for each treatment in each experiment, and every experiment was repeated for three times). ${ }^{* *} p<0.01$ compared with the $\mathrm{iA} \beta_{1-42}+$ M group. E, Phenol red did not affect morphine protection. Morphine protection was examined in culture medium with or without phenol red for $24 \mathrm{~h}$ (200 cells were injected for each treatment in each experiment, and every experiment was repeated 3 times). ${ }^{* *} p<0.01$ compared with the control group. $F$, Left, Immunostaining (top) and Western blot (bottom) showed the presence of MORs in MCF-7 and MDA-MB231 cells. Right, Luciferase reporter assay data showed that morphine induced ER activation in MCF-7 and MDA-MB231 cells transfected with ER at $24 \mathrm{~h}$ (repeated in 3 independent preparations). ${ }^{*} p<0.05 ;{ }^{* *} p<0.01$ compared with the control group. Data are presented as mean $\pm \mathrm{SE}$.

of BACE-1 and BACE-2 mRNA in morphine, naloxone, tamoxifen, and combined treatment groups. Morphine increased both BACE- 1 and BACE- 2 mRNA levels after $2 \mathrm{~h}$ of treatment. Naloxone reversed the upregulation of both BACE-1 and BACE-2
mRNA levels by morphine, suggesting such an increase was mediated through opioid receptors (Fig. 4I). Tamoxifen also increased both BACE- 1 and BACE- 2 mRNA levels. In the presence of tamoxifen, morphine increased both BACE-1 and BACE-2 
A

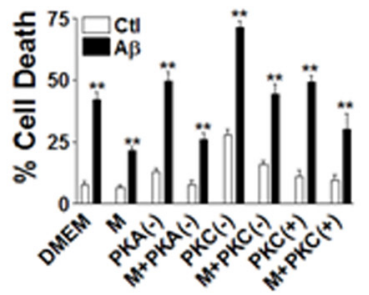

C

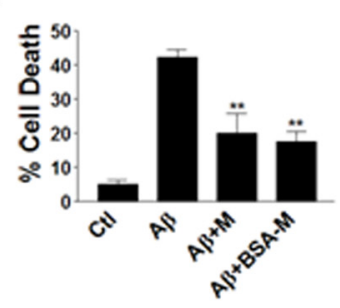

G

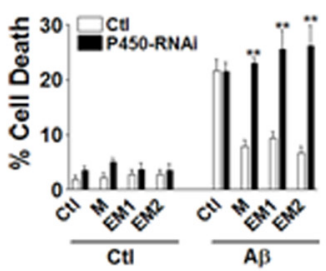

I

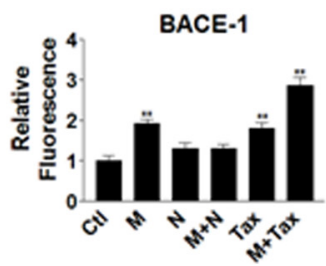

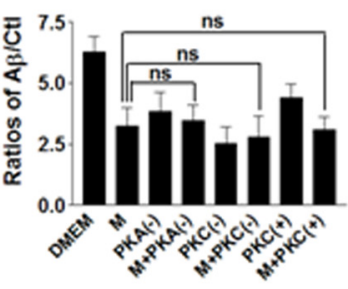

D

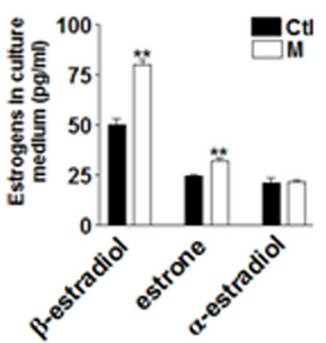

H
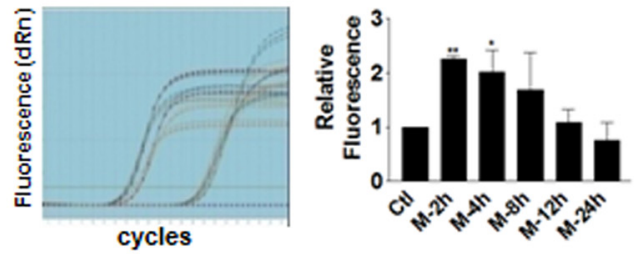

E

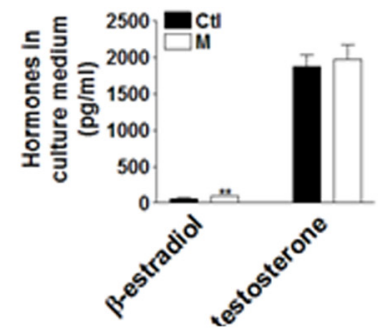

F

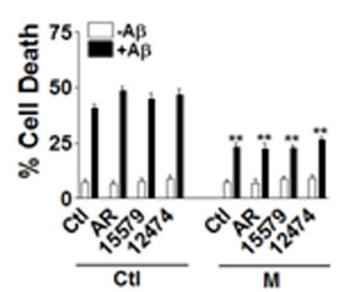

Figure 4. Morphine triggered estradiol release by neurons. A, Left, PKA inhibitor [PKA $(-)]$, PKC inhibitor [PKC ( -$)]$, and PKC activator [PKC $(+)]$ were added to morphine treatment for $24 \mathrm{~h}(200$ cells were injected for each treatment in each experiment, and every experiment was repeated 3 times). ${ }^{* *} p<0.01$ compared with the control group. Right, Ratios of $A \beta$ to control were calculated and plotted. There were no significant differences (ns) between morphine treatment alone and PKA $(-)$, PKC $(-)$, or PKC $(+)(200$ cells were injected for each treatment in each experiment and every experiment was repeated 3 times) compared with the M group. B, Left, PKAl and its mutant PKAIM were coinjected and treated by morphine for $24 \mathrm{~h}$ ( $200 \mathrm{cells}$ were injected for each treatment in each experiment, and every experiment was repeated 3 times). ${ }^{* *} p<0.01$ compared with the control group. Right, Ratios of A $\beta$ to control were calculated and plotted. There were no significant differences between morphine treatment alone and PKAI or PKAIM compared with M group (200 cells were injected for each treatment in each experiment, and every experiment was repeated 3 times). C, BSA-M still had protective effects at $24 \mathrm{~h}$ (200 cells were injected for each treatment in each experiment, and every experiment was repeated 3 times). ${ }^{* *} p<0.01$, compared with the $\mathrm{iA} \beta_{1-42}$ group. $\boldsymbol{D}$, Morphine treatment induced increased levels of $\beta \mathrm{E}_{2}$ and estrone, but not $\alpha \mathrm{E}_{2}$ in culture medium at $24 \mathrm{~h}$ measured by LC-MS/MS (repeated in 3 independent preparations). ${ }^{* *} p<$

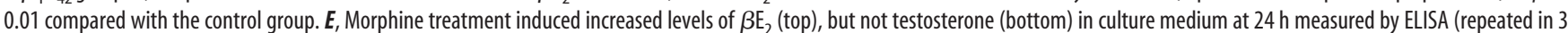
independent preparations). ${ }^{* *} p<0.01$ compared with the control group. $F$, Wild-type AR and mutant AR $(15579,12474)$ did not alter morphine protection at $24 \mathrm{~h}$ (200 cells were injected for each treatment in each experiment, and every experiment was repeated 3 times). ${ }^{* *} p<0.01$ compared with the iA $\beta_{1-42}$ group. G, siRNA to P450 cytochrome aromatase (P450-RNAi) blocked morphine protection at $24 \mathrm{~h}$ ( 200 cells were injected for each treatment in each experiment, and every experiment was repeated 3 times). ${ }^{* *} p<0.01$ compared with the $\mathrm{iA} \beta_{1-42}+\mathrm{M}$, iA $\beta_{1-42}+\mathrm{EM}-1$, iA $\beta_{1-42}+$ EM-2 groups. $\boldsymbol{H}$, Left, Fluorescence recorded from real-time PCR (45 cycles). Right, Quantification of real-time PCR suggests that morphine treatment at 2 and $4 \mathrm{~h}$ increased levels of P450 cytochrome aromatase significantly (repeated in 3 independent preparations). ${ }^{*} p<0.05 ;{ }^{* *} p<0.01$ compared with the control group. Data are presented as mean \pm SE. $I$, The levels of mRNA of BACE-1 (left) and BACE-2 (right) were measured after $2 \mathrm{~h}$ treatment of morphine, naloxone, Tax, and combinations (repeated in 3 independent preparations). ${ }^{* *} p<0.01$ compared with the control group. J, BACE- 1 and $\gamma$-secretase activities measured with or without the presence of morphine (repeated in 3 independent preparations). ${ }^{* *} p<0.01$ compared with the control group. $\boldsymbol{K}$, Morphine did not alter the production of $\mathrm{A} \beta_{1-40}$ or $\mathrm{A} \beta_{1-42}$ in APP/PS1 mouse hippocampal tissues (repeated in 3 independent preparations). Data are presented as mean \pm SE.

mRNA to greater levels, suggesting an additive effect of morphine and tamoxifen on regulating BACE-1 and BACE-2 (Fig. 4I). The activities of BACE- 1 and $\gamma$-secretase were measured, and our data showed that with the presence of morphine, BACE-1 activity increased, whereas $\gamma$-secretase activity decreased (Fig. $4 J$ ). Since BACE- 1 and $\gamma$-secretase activities were suggested to change A $\beta$ production, the levels of $\mathrm{A} \beta_{1-40}$ and $\mathrm{A} \beta_{1-42}$ in the hippocampal tissue of APP/PS1 mice with or without morphine treatment (500 $\mu \mathrm{M}, 1.2 \mu \mathrm{l})$ were measured. After $24 \mathrm{~h}$ of treatment, the produc- tion of $\mathrm{A} \beta_{1-40}$ and $\mathrm{A} \beta_{1-42}$ did not show significant alterations (Fig. $4 K)$.

Estradiol release induced by morphine was responsible for morphine protection

To address whether morphine protection against iA $\beta$ toxicity could be explained completely by estradiol release induced by morphine, neurons were treated under two procedures: pretreatment and posttreatment. In the pretreatment procedure, the first 
batch of neurons were treated with either control medium or morphine for $24 \mathrm{~h}$, the conditioned medium was then taken out from these neurons and given to the second batch of neurons for a $24 \mathrm{~h}$ treatment, and the data were collected after conditioned medium treatment. In the posttreatment procedure, neurons were only treated with or without morphine for $24 \mathrm{~h}$ (Fig. 5A). When comparing morphine protection induced by the two procedures, there was no significant difference (Fig. 5B). Since morphine also induced an increase in $\mathrm{ER} \alpha$ levels (Fig. 5C), the effects of overexpression of $\mathrm{ER} \alpha$ were also investigated. Overexpression of $\mathrm{ER} \alpha$ by microinjecting wild-type ER in neurons dramatically enhanced morphine protection in the pretreatment procedure, while ER $\triangle D B D$ and ER siRNA blocked this effect, suggesting that morphine induced estrogen release and increase of $\operatorname{ER} \alpha$ both contributed to morphine protection (Fig. 5D).

In the pretreatment procedure, the conditioned medium from the control group contained only morphine, and the conditioned medium from the morphine-treated group contained both morphine and released estradiol. To distinguish the protective effects by morphine and released estradiol, the conditioned medium was absorbed by estradiol antibody or morphine antibody, and then added to the second batch of neurons to observe morphine protection. When the conditioned medium was absorbed by $\beta \mathrm{E}_{2}$ or morphine antibody alone, with the overexpression of ER, there were still a significant amount of morphine protection (Fig. 5E,F), indicating that both estradiol and morphine contributed to morphine protection. When the conditioned medium was absorbed by $\beta \mathrm{E}_{2}$ and morphine antibodies together, or first by morphine antibody and then second by the $\beta \mathrm{E}_{2}$ antibody, morphine protection was completely abolished (Fig. 5G,H). Using rabbit IgG for absorption did not change morphine protection (Fig. 5I). Comparison of the data from Figure 5, $F$ and $H$, indicated that, with ER overexpression, morphine protection can be explained completely by its induction of estrogen release.

Heat shock protein 70 was involved in morphine protection The data above show that morphine protection against iA $\beta$ depends on morphine-induced estrogen release by neurons and upregulation of ER $\alpha$. It was reported that the protective effects of estrogen against iA $\beta$ in human primary neurons were mediated by Hsp70 (Zhang et al., 2004). Therefore, the involvement of Hsp70 was examined in morphine protection in the current study. Heat shock transcription factor-1 (HSF1) knock-out mice did not produce Hsp70 or other members of heat shock family (McMillan et al., 1998). The presence of both ER and MOR was first confirmed in the neuronal culture of hippocampus from HSF $1-/-$ mice to ensure these mice could respond to both estrogen and morphine (Fig. 6A).

When infected with iA $\beta$-expressing virus, cell death, measured by TUNEL, from the hippocampus CA1 area of $H S F 1-/-$ mice increased to $\sim 250 \%$ compared to control EGFP virus infection (Fig. $6 B$ ). Morphine (500 $\mu \mathrm{M} ; 1.2 \mu \mathrm{l})$ reduced cell death in WT mice but not in $H S F 1-/-$ mice, suggesting that Hsps might be involved in morphine protection (Fig. 6B). To further identify which Hsps were responsible for morphine protection, recombinant Hsp70 was microinjected with $\mathrm{A} \beta_{1-42}$ peptide into cultured rat hippocampal neurons. Without morphine application, Hsp70 induced $\sim 60 \%$ protection, whereas control protein BSA did not protect at all (Fig. 6C). To associate Hsp70 and morphine protection together, the expression levels of Hsp70 with or without morphine treatment were first examined. Western blot data showed that morphine induced a remarkable increase of Hsp70
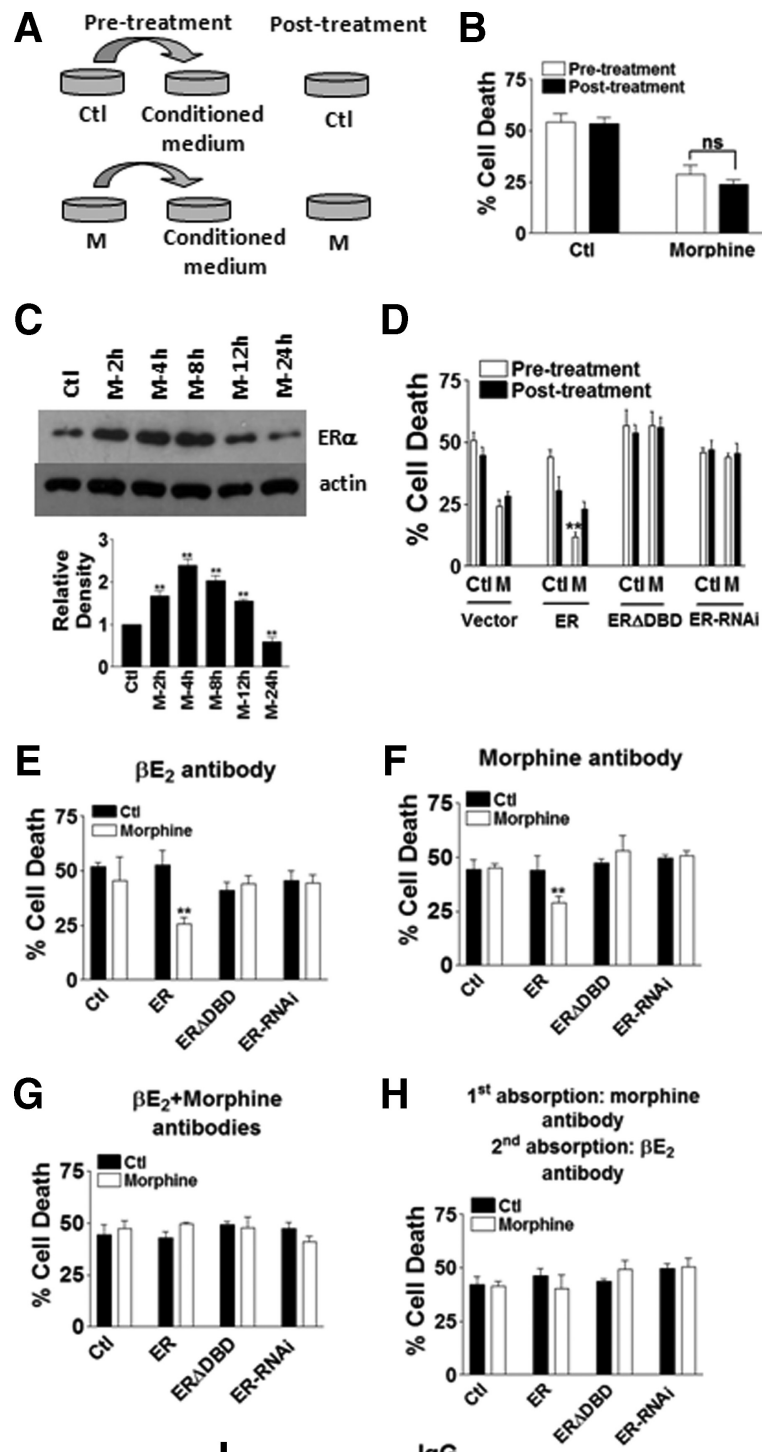
$2^{\text {nd }}$ absorption: $\beta \mathrm{E}_{2}$

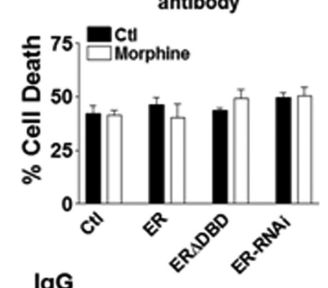

I

$\lg \mathbf{G}$

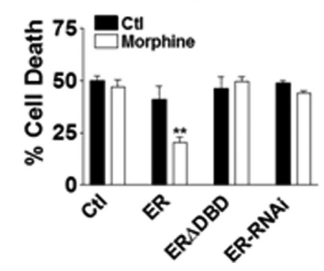

Figure 5. Estradiol release induced by morphine was responsible for morphine protection. $\boldsymbol{A}$, Experimental procedures for pretreatment and posttreatment. $\boldsymbol{B}$, There was no significant difference (ns) between pretreatment and posttreatment of morphine at $24 \mathrm{~h}$ (200 cells were counted for each treatment in each experiment, and every experiment was repeated 3 times). C, Top, Western blot showing the levels of ER $\alpha$ and actin with 2 to $24 \mathrm{~h}$ morphine treatments. Bottom, Quantification of of ER $\alpha$ levels from Western blot at specified time points (repeated in 3 independent preparations). ${ }^{* *} p<0.01$ compared with the control group. D, Morphine protection was significantly increased with ER overexpression in pretreatment at $24 \mathrm{~h}$ (200 cells were injected for each treatment in each experiment, and every experiment was repeated 3 times). ${ }^{* *} p<0.01$ compared with the control group. $\boldsymbol{E}$, Conditioned medium from the pretreatment procedure was absorbed by $\beta \mathrm{E}_{2}$ antibody and then added to neurons for $24 \mathrm{~h}$. $\boldsymbol{F}$, Conditioned medium from the pretreatment procedure was absorbed by morphine antibody and then added to neurons for $24 \mathrm{~h}$. $G$, Conditioned medium from the pretreatment procedure was absorbed by $\beta \mathrm{E}_{2}$ and morphine antibodies and then added to neurons for $24 \mathrm{~h}$. $\boldsymbol{H}$, Conditioned medium from the pretreatment procedure was first absorbed by morphine antibody and then by $\beta \mathrm{E}_{2}$ antibody, and then added to neurons for $24 \mathrm{~h}$. I, Conditioned medium from the pretreatment procedure was absorbed by control lg G and then added to neurons for $24 \mathrm{~h}$ ( 200 cells were injected for each treatment in each experiment, and every experiment was repeated 3 times). ${ }^{* *} p<0.01$ compared with the control group. Data are presented as mean $\pm \mathrm{SE}$. 


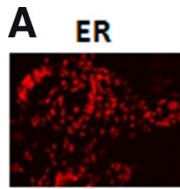

DAPI

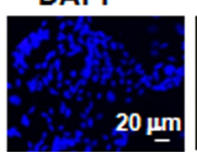

B

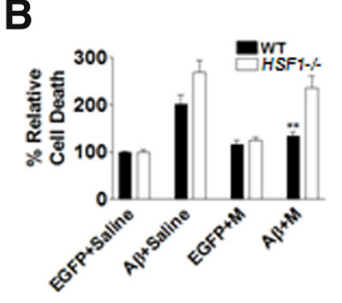

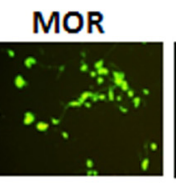

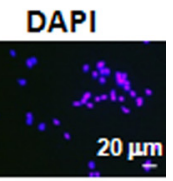

C
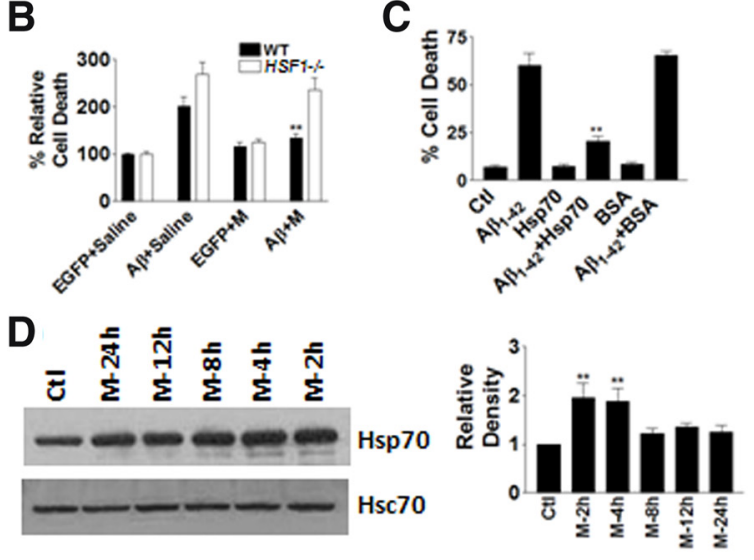

E
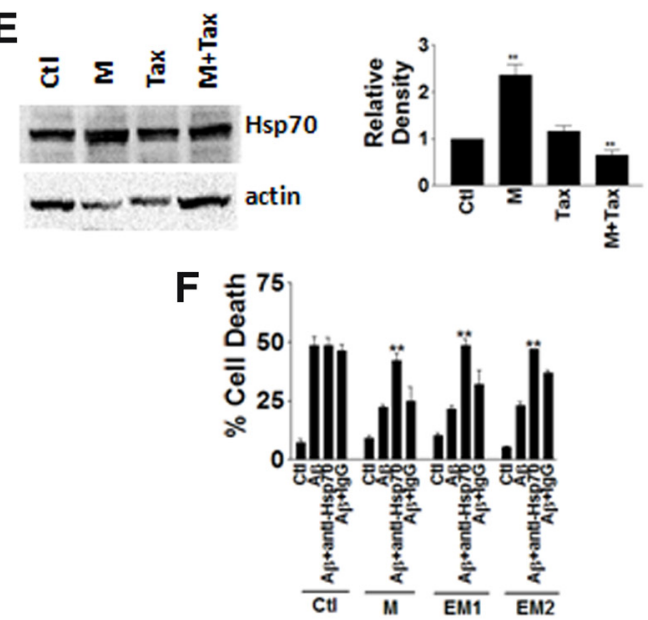

G

Control

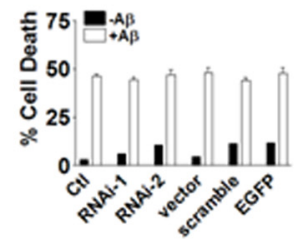

EM-1
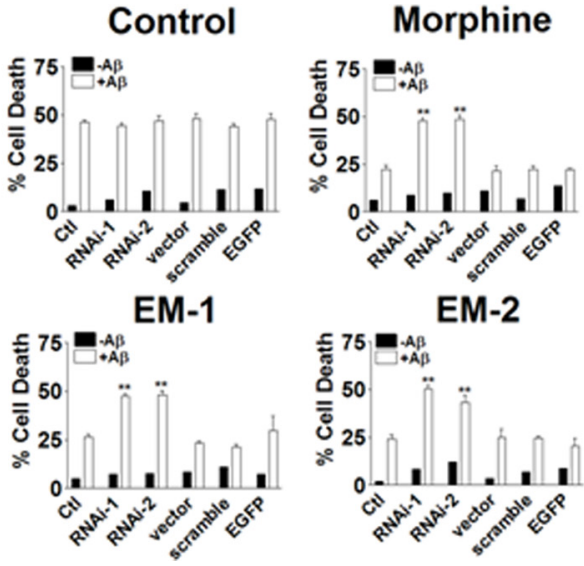

EM-2

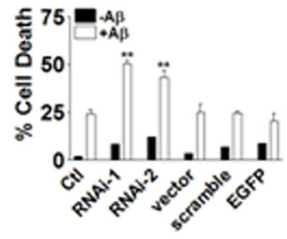

Figure 6. Heat shock protein 70 was involved in morphine protection. $\boldsymbol{A}$, Primary neuronal cultures of the hippocampal regions from HSF1 knock-out (HSF1-/-) mice stained with ER or MOR antibodies. $\boldsymbol{B}$, Mouse hippocampus CA1 areas were injected with EGFP-expressing or $\mathrm{iA} \beta_{1-42}$-expressing Adeno-5 virus. Morphine greatly increased cell survival in the $\mathrm{i} A \beta_{1-42}$ group at $24 \mathrm{~h}$ ( 200 cells were counted for each treatment in each experiment, and every experiment was repeated 3 times). ${ }^{* *} p<0.01$ compared with the $\mathrm{i} A \beta_{1-42}$ group. $\boldsymbol{C}, \mathrm{Hsp} 70$ protected hippocampal neurons in culture from iA $\beta_{1-42}$ toxicity at $24 \mathrm{~h}$ (200 cells were injected for each treatment in each experiment, and every experiment was repeated 3 times). ${ }^{* *} p<0.01$ compared with the iA $\beta_{1-42}$ group. D, Morphine induced increase of Hsp70 levels in 2 and $4 \mathrm{~h}$ treatments (repeated in 3 independent preparations). ${ }^{* *} p<0.01$ compared with the control group. $\boldsymbol{E}$, Tax blocked Hsp70 increase induced by morphine at $2 \mathrm{~h}$ (repeated in 3 independent preparations). ${ }^{* *} p<0.01$ compared with the control group. $\boldsymbol{F}$, Hsp70 antibody blocked M, level in cultured hippocampal neurons (Fig. 6D). Tax effectively blocked morphine induced Hsp70 upregulation, suggesting that ER activation was involved in morphine-induced Hsp70 upregulation (Fig. 6E). Depletion of Hsp70 function by Hsp70neutralizing antibody (Fig. $6 F$ ) and two siRNAs to Hsp70 (Fig. $6 G$ ) completely blocked morphine, EM-1, and EM-2 protection, indicating that $\mathrm{Hsp} 70$ was required for morphine protection.

\section{Hsp70 protected against iA $\beta$ toxicity by increasing proteasomal activity}

Cytotoxicity of iA $\beta$ was showed to be induced by p53 activation, Bax, and caspase- 6 in human primary neurons (Zhang et al., 2002). Whether Hsp70 protected against p53, Bax, or caspase- 6 was examined first. Recombinant Hsp70 was comicroinjected with p53 wild-type or dominant-negative constructs, recombinant $\mathrm{Bax}, \mathrm{Bcl}_{2}$, or caspase-6 (Fig. $7 A-C$ ). Our data showed that Hsp70 did not protect against p53, Bax, or caspase-6 toxicity when these proapoptotic factors microinjected alone without iA $\beta$ into neurons (Fig. $7 A-C$ ). iA $\beta$ was reported to impair proteasome degradation (Ohyagi, 2008); therefore, we asked the question of whether Hsp70 prevented iA $\beta$ toxicity through rescuing proteasome degradation. Measured proteasomal activity showed that Hsp70 reversed the changes induced by iA $\beta_{1-42}$ (Fig. $7 D)$. Proteasome inhibitor MG-132 (0.5, 1, and $10 \mu \mathrm{M})$ blocked Hsp70 protection, suggesting that Hsp70 recovered proteasomal activity impaired by iA $\beta$ (Fig. $7 E$ ). To further test this hypothesis, Ub-EGFP was microinjected into neurons. Under normal condition, ubiquitin was rapidly degraded by proteasome; therefore, at $24 \mathrm{~h}$ after injection, there were only a few EGFP spots detected (Fig. 7F, left). With impaired proteasomal activity induced by proteasome inhibitor MG-132 $(0.5 \mu \mathrm{M})$ or lactacystein $(20 \mu \mathrm{M})$, EGFP accumulated in more cells (Fig. $7 F$, middle, right). Coinjection of Hsp70 and $\mathrm{A} \beta_{1-42}$ peptide or $\mathrm{A} \beta_{1-42} \mathrm{cDNA}$ construct effectively reversed the impairment of proteasomal activity induced by iA $\beta$ (Fig. $7 G, H$ ), suggesting that Hsp70 protection might be mediated through improved proteasomal activity.

\section{Discussion}

In the present study, we find that morphine as well as EM-1 and EM-2 can reduce iA $\beta$ toxicity in human neuronal culture, rat hippocampal neuronal culture, and rat brain in vivo. Morphine reverses the electrophysiological changes induced by iA $\beta$ in cultured hippocampal neurons, including current density, resting membrane potential, and capacitance. Also, morphine improves the spatial memory performance of APP/PS1 mice and rats infected by iA $\beta$ packaged virus in Morris water maze tests. These in vivo data suggest that morphine can improve functions of neuronal transmission and cognitive performance.

Morphine is indicated to modulate cell death/survival and play antiapoptotic roles in neurons of the CNS. However, the mechanisms of morphine protection are not clear yet. Morphine preconditioning-induced ischemia tolerance is mediated through novel PKCe (nPKCe) isoform and NMDA receptors since morphine protection is greatly reduced by $\mathrm{nPKC} \varepsilon$ and NMDA receptor-specific antagonists or by blockage of mem-

EM-1, and EM-2 protections at $24 \mathrm{~h}$ (200 cells were injected for each treatment in each experiment, and every experiment was repeated 3 times). ${ }^{* *} p<0.01$ compared with the $\mathrm{iA} \beta_{1-42}+$ $M$, iA $\beta_{1-42}+E M-1$, and iA $\beta_{1-42}+$ EM-2 groups. G, Two siRNAs to Hsp70 (RNAi-1 and RNAi-2) blocked M, EM-1, and EM-2 protections at $24 \mathrm{~h}$ (200 cells were injected for each treatment in each experiment, and every experiment was repeated 3 times). ${ }^{* *} p<0.01$ compared with the $\mathrm{iA} \beta_{1-42}+\mathrm{M}, \mathrm{iA} \beta_{1-42}+\mathrm{EM}-1$, and $\mathrm{iA} \beta_{1-42}+\mathrm{EM}-2$ groups. Data are presented as mean $\pm \mathrm{SE}$. 
A

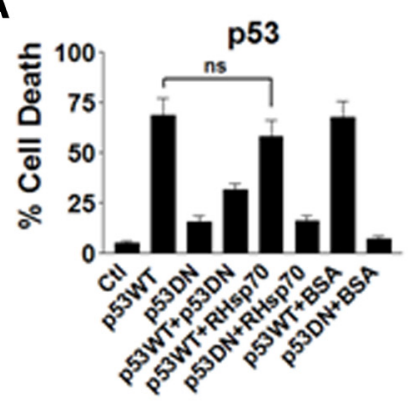

D

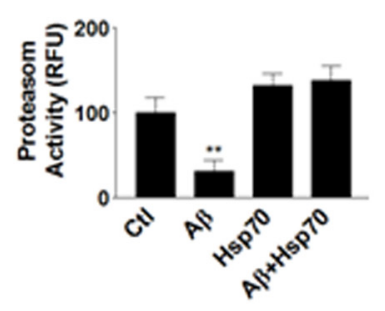

B

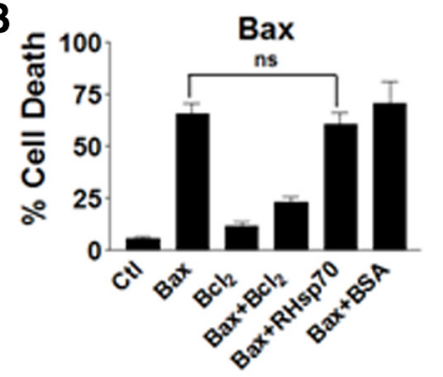

C

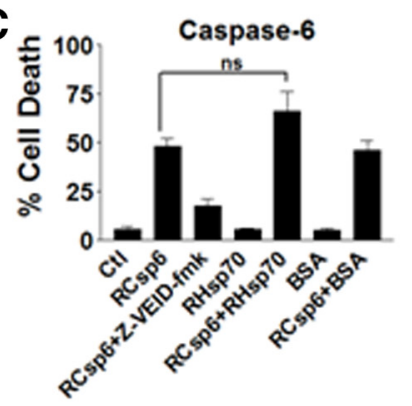

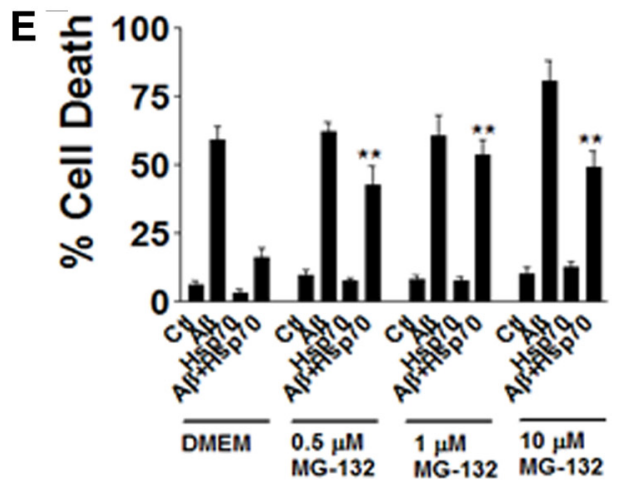

F

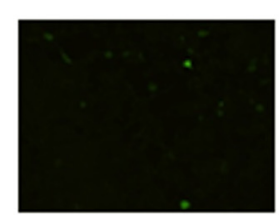

Ub-EGFP

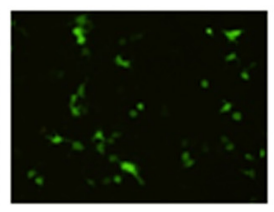

MG-132

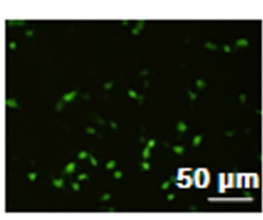

lactacystein

G
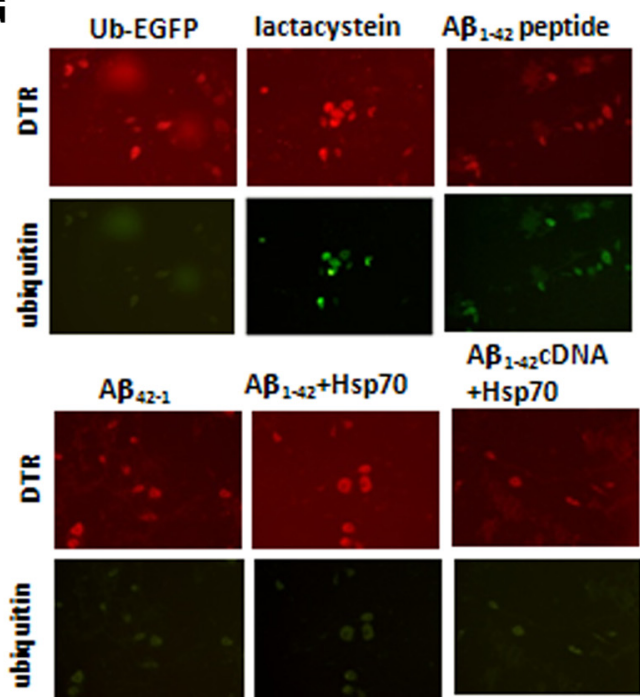

$\mathrm{AB}_{142} \mathrm{CDNA}$ $+\mathrm{Hsp} 70$

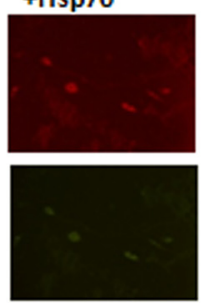

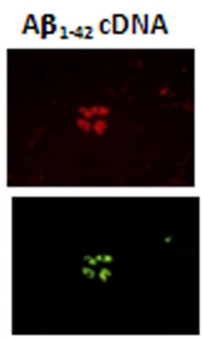

$\mathrm{A \beta}_{1-42}+\mathrm{Hsp} 70$ +lactacystein
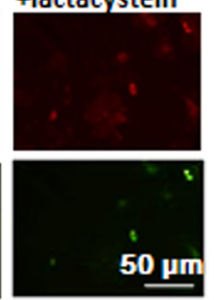

H

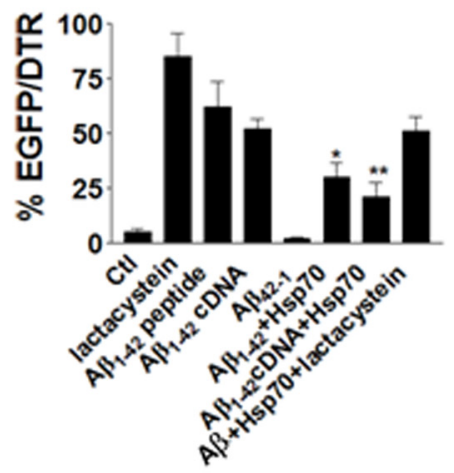

I Estrogen

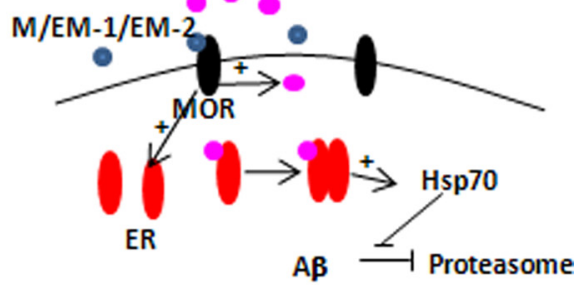

Figure 7. Hsp70 protected against iA $\beta$ toxicity by increasing proteasomal activity. A-C, Recombinant Hsp70 was comicroinjected into neurons with p53 wild-type or dominantnegative constructs $(\boldsymbol{A})$, recombinant $\mathrm{Bax}, \mathrm{BCl},(\boldsymbol{B})$, or caspase-6 $(\boldsymbol{C})$ at $24 \mathrm{~h}$ (200 cells were injected for each treatment in each experiment, and every experiment was repeated 3 times). $D$, Hsp70 itself protected against iA $\beta_{1-42}$ toxicity at $24 \mathrm{~h}$ (200 cells were injected for each treatment in each experiment, and every experiment was repeated 3 times). ${ }^{* *} p<0.01$ compared with the $\mathrm{i} A \beta_{1-42}$ groups. $E$, Proteasome inhibitor MG-132 blocked Hsp70 protection at $24 \mathrm{~h}$ (200 cells were injected for each treatment in each experiment, and every experiment was repeated 3 times). ${ }^{* *} p<0.01$, compared with $\mathrm{iA} \beta_{1-42}+$ Hsp70 groups. $\boldsymbol{F}$, Ub-EGFP was used as an indicator for proteasomal activity at $24 \mathrm{~h}$. $\boldsymbol{G}$, Hsp70 rescued proteasomal activity impaired by iA $\beta_{1-42}$ at $24 \mathrm{~h}$. $\boldsymbol{H}$, Quantification of $A \beta$ degradation associated with ubiquitin by number of EGFP-positive cells over DTR-positive cells (200 cells were injected for each treatment in each experiment, and every experiment was repeated 3 times). ${ }^{* *} p<0.01$ compared with the iA $\beta_{1-42}$ groups. Data are presented as mean $\pm S E$. $I$, Schematic drawing of morphine protection pathway. Morphine, EM-1, or EM-2 induced estrogen release by neurons and upregulation of ER through binding to their receptor MOR on cell membrane. Activated $\mathrm{ER}$ then induced increase of $\mathrm{Hsp} 70$, which rescued proteasomal activity impaired by iA $\beta$. 
brane translocations of $\mathrm{nPKC} \varepsilon$ and NMDA receptors in mouse hippocampal slices (Liu et al., 2001; Fanjun et al., 2006). It is proposed that morphine-induced nitrogen oxide release mediates neuroprotection in a human neuroblastoma cell line against intracellular oxidative stress and neuroinflammation (Rambhia et al., 2005). Protection of morphine against peroxynitriteinduced apoptosis in primary rat neonatal astrocytes is mediated by phosphoinositide 3-kinase (Kim et al., 2001). Morphine decreases BACE-1 mRNA while increasing BACE-2 mRNA in human neuroblastoma HTB-11 cells. Downregulation of BACE-1 and upregulation of BACE- 2 has been shown to decrease $\mathrm{A} \beta$ levels; therefore, morphine is suggested to be protective against extracellular A $\beta$ toxicity (Pak et al., 2005). Our data showed that morphine increases both BACE-1 and BACE- 2 mRNA in primary rat hippocampal neurons. In APP/PS1 mouse hippocampal tissues, morphine does not alter $\mathrm{A} \beta_{1-40}$ or $\mathrm{A} \beta_{1-42}$ production significantly. The differences between our data and the results reported by Pak et al. (2005) may be explained by cell-type specificity.

In this study, we find that morphine protection is mediated by inducing estradiol release from hippocampal neurons, possibly by increasing P450 cytochrome aromatase expression and therefore upregulating its activity. Released estrogen induces upregulation of Hsp70 through binding to its receptor ER, which is consistent with the fact that morphine induces Hsp70 and Hsp27 mRNA upregulation in rat brains (Ammon-Treiber et al., 2004). Hsp70 protects against intracellular amyloid toxicity by increasing proteasomal activity that is reduced by iA $\beta$ (Fig. 7I). We also provide a novel mechanism for morphine action: induction of estradiol release by neurons, which is protective against iA $\beta$ toxicity in our case. Although estrogen secretion by hippocampal neurons is described previously (Kretz et al., 2004; Prange-Kiel et al., 2006, 2008), this is the first time, to our knowledge, that induction of estradiol release in hippocampal neurons by morphine is reported. The efficacy of estrogen replacement therapy has been debated for a long time, and cognitive function is not necessarily improved after the therapy (Birge, 1996; Schneider and Finch, 1997; Mulnard, 2000; LeBlanc, 2002). Transgenic rodent models of $\mathrm{AD}$ show that elevated estrogen levels reduce deposition of $A \beta$ in the brain (Pinkerton and Henderson, 2005). However, some studies have identified that estrogen replacement therapy improves senescent memory loss or functional decline in postmenopausal women (Kawas et al., 1997; Baldereschi et al., 1998; Yaffe et al., 1998; Maki and Resnick, 2001), while others demonstrated no benefits (Rapp et al., 2003; Shumaker et al., 2003; Galen Buckwalter et al., 2004; Kang et al., 2004). We think this may, at least partially, be attributed to the loss of estrogen receptors after menopause. Some studies suggest that early treatment of estrogen is beneficial, while others cannot reach specific conclusions. Therefore, even through our data show that morphine stimulates estrogen release by neurons and plays a protective role against amyloid toxicity, how to apply this knowledge to disease therapy in a chronic situation still needs extensive studies. On the other hand, because morphine has great side effects such as tolerance, physical dependence, respiratory suppression, and constipation (Zhang et al., 2008), which greatly limit its medical and clinical applications, alternatives should be developed to overcome these side effects. Our data also indicate that EM- 1 and EM-2 can also reduce iA $\beta$-induced cell death, suggesting that stimulating the release of endogenous EMs might be one of these alternatives. In our study, morphine upregulates P450 cytochrome aromatase expression. Evidence shows that cAMP and its analog inhibit P450 activity (Lephart, 1996). On the other hand, acute and chronic treatments of morphine are demonstrated to decrease cAMP levels in the brain (Duman et al., 1988). It is possible that morphine upregulates $\mathrm{P} 450$ levels through decreasing cAMP. A better understanding of morphine action mechanisms will help to develop new technologies and treatments to maximize its benefits and limit its side effects. These efforts will eventually lead to new clinical potentials for this ancient drug.

\section{References}

Ammon-Treiber S, Grecksch G, Stumm R, Riechert U, Tischmeyer H, Reichenauer A, Hollt V (2004) Rapid, transient, and dose-dependent expression of hsp70 messenger RNA in the rat brain after morphine treatment. Cell Stress Chaperones 9:182-197.

Ammon-Treiber S, Stolze D, Schroder H, Loh H, Hollt V (2005) Effects of opioid antagonists and morphine in a hippocampal hypoxia/hypoglycemia model. Neuropharmacology 49:1160-1169.

Avdoshina V, Biggio F, Palchik G, Campbell LA, Mocchetti I (2010) Morphine induces the release of CCL5 from astrocytes: potential neuroprotective mechanism against the HIV protein gp120. Glia 58:1630-1639.

Baldereschi M, Di Carlo A, Lepore V, Bracco L, Maggi S, Grigoletto F, Scarlato G, Amaducci L (1998) Estrogen-replacement therapy and Alzheimer's disease in the Italian Longitudinal Study on Aging. Neurology 50:996-1002.

Berthois Y, Katzenellenbogen JA, Katzenellenbogen BS (1986) Phenol red in tissue culture media is a weak estrogen: implications concerning the study of estrogen-responsive cells in culture. Proc Natl Acad Sci U S A 83:2496-2500.

Birge SJ (1996) Is there a role for estrogen replacement therapy in the prevention and treatment of dementia? J Am Geriatr Soc 44:865-870.

Blanchard V, Moussaoui S, Czech C, Touchet N, Bonici B, Planche M, Canton T, Jedidi I, Gohin M, Wirths O, Bayer TA, Langui D, Duyckaerts C, Tremp G, Pradier L (2003) Time sequence of maturation of dystrophic neurites associated with Abeta deposits in APP/PS1 transgenic mice. Exp Neurol 184:247-263.

Charron C, Messier C, Plamondon H (2008) Neuroprotection and functional recovery conferred by administration of kappa- and delta 1-opioid agonists in a rat model of global ischemia. Physiol Behav 93:502-511.

Cui J, Chen Q, Yu LC, Zhang Y (2008) Chronic morphine application is protective against cell death in primary human neurons. Neuroreport 19:1745-1749.

Day RN, Walder JA, Maurer RA (1989) A protein kinase inhibitor gene reduces both basal and multihormone-stimulated prolactin gene transcription. J Biol Chem 264:431-436.

Duman RS, Tallman JF, Nestler EJ (1988) Acute and chronic opiateregulation of adenylate cyclase in brain: specific effects in locus coeruleus. J Pharmacol Exp Ther 246:1033-1039.

Fanjun M, Junfa L, Bingxi Z, Fang J (2006) nPKCepsilon and NMDA receptors participate in neuroprotection induced by morphine pretreatment. J Neurosurg Anesthesiol 18:119-124.

Farooqui M, Geng ZH, Stephenson EJ, Zaveri N, Yee D, Gupta K (2006) Naloxone acts as an antagonist of estrogen receptor activity in MCF-7 cells. Mol Cancer Ther 5:611-620.

Galen Buckwalter J, Crooks VC, Robins SB, Petitti DB (2004) Hormone use and cognitive performance in women of advanced age. J Am Geriatr Soc 52:182-186.

Good TA, Murphy RM (1996) Effect of beta-amyloid block of the fastinactivating $\mathrm{K}+$ channel on intracellular $\mathrm{Ca} 2+$ and excitability in a modeled neuron. Proc Natl Acad Sci U S A 93:15130-15135.

Hou JF, Cui J, Yu LC, Zhang Y (2009) Intracellular amyloid induces impairments on electrophysiological properties of cultured human neurons. Neurosci Lett 462:294-299.

Kang DH, Yu ES, Yoon KI, Johnson R (2004) The impact of gender on progression of renal disease: potential role of estrogen-mediated vascular endothelial growth factor regulation and vascular protection. Am J Pathol 164:679-688.

Kawas C, Resnick S, Morrison A, Brookmeyer R, Corrada M, Zonderman A, Bacal C, Lingle DD, Metter E (1997) A prospective study of estrogen replacement therapy and the risk of developing Alzheimer's disease: the Baltimore Longitudinal Study of Aging. Neurology 48:1517-1521.

Kim HS, Park CH, Cha SH, Lee JH, Lee S, Kim Y, Rah JC, Jeong SJ, Suh YH (2000) Carboxyl-terminal fragment of Alzheimer's APP destabilizes calcium homeostasis and renders neuronal cells vulnerable to excitotoxicity. Faseb J 14:1508-1517. 
Kim MS, Cheong YP, So HS, Lee KM, Kim TY, Oh J, Chung YT, Son Y, Kim BR, Park R (2001) Protective effects of morphine in peroxynitriteinduced apoptosis of primary rat neonatal astrocytes: potential involvement of $\mathrm{G}$ protein and phosphatidylinositol 3-kinase (PI3 kinase). Biochem Pharmacol 61:779-786.

Klepstad P, Skogvoll E, Kaasa S, Borchgrevink PC (2000) Circadian distribution of oral opioid consumption in cancer patients. Methods Find Exp Clin Pharmacol 22:753-755.

Kretz O, Fester L, Wehrenberg U, Zhou L, Brauckmann S, Zhao S, PrangeKiel J, Naumann T, Jarry H, Frotscher M, Rune GM (2004) Hippocampal synapses depend on hippocampal estrogen synthesis. J Neurosci 24:5913-5921.

LeBlanc A (1995) Increased production of $4 \mathrm{kDa}$ amyloid beta peptide in serum deprived human primary neuron cultures: possible involvement of apoptosis. J Neurosci 15:7837-7846.

LeBlanc A (2002) Estrogen and Alzheimer's disease. Curr Opin Investig Drugs 3:768-773.

Lephart ED (1996) A review of brain aromatase cytochrome P450. Brain Res Brain Res Rev 22:1-26.

Li M, Chen L, Lee DH, Yu LC, Zhang Y (2007) The role of intracellular amyloid beta in Alzheimer's disease. Prog Neurobiol 83:131-139.

Liu H, McPherson BC, Yao Z (2001) Preconditioning attenuates apoptosis and necrosis: role of protein kinase $\mathrm{C}$ epsilon and -delta isoforms. Am J Physiol Heart Circ Physiol 281:H404-410.

Liu Y, Nie YM, Wu WK (2008) [The effect of PKC activation and Smac release on inhibition of myocardial cell apoptosis by Sini Decoction]. Zhong Yao Cai 31:1675-1678.

Maki PM, Resnick SM (2001) Effects of estrogen on patterns of brain activity at rest and during cognitive activity: a review of neuroimaging studies. Neuroimage 14:789-801.

McMillan DR, Xiao X, Shao L, Graves K, Benjamin IJ (1998) Targeted disruption of heat shock transcription factor 1 abolishes thermotolerance and protection against heat-inducible apoptosis. J Biol Chem 273:7523-7528.

Mulnard RA (2000) Estrogen as a treatment for Alzheimer disease. JAMA 284:307-308.

Ohyagi Y (2008) Intracellular amyloid beta-protein as a therapeutic target for treating Alzheimer's disease. Curr Alzheimer Res 5:555-561.

Pak T, Cadet P, Mantione KJ, Stefano GB (2005) Morphine via nitric oxide modulates beta-amyloid metabolism: a novel protective mechanism for Alzheimer's disease. Med Sci Monit 11:BR357-BR366.

Pinkerton JV, Henderson VW (2005) Estrogen and cognition, with a focus on Alzheimer's disease. Semin Reprod Med 23:172-179.

Prange-Kiel J, Fester L, Zhou L, Lauke H, Carretero J, Rune GM (2006) Inhibition of hippocampal estrogen synthesis causes region-specific downregulation of synaptic protein expression in hippocampal neurons. Hippocampus 16:464-471.

Prange-Kiel J, Jarry H, Schoen M, Kohlmann P, Lohse C, Zhou L, Rune GM (2008) Gonadotropin-releasing hormone regulates spine density via its regulatory role in hippocampal estrogen synthesis. J Cell Biol 180:417-426.

Price DL, Sisodia SS (1998) Mutant genes in familial Alzheimer's disease and transgenic models. Annu Rev Neurosci 21:479-505.

Qian L, Tan KS, Wei SJ, Wu HM, Xu Z, Wilson B, Lu RB, Hong JS, Flood PM
(2007) Microglia-mediated neurotoxicity is inhibited by morphine through an opioid receptor-independent reduction of NADPH oxidase activity. J Immunol 179:1198-1209.

Rambhia S, Mantione KJ, Stefano GB, Cadet P (2005) Morphine modulation of the ubiquitin-proteasome complex is neuroprotective. Med Sci Monit 11:BR386-BR396.

Rapp SR, Espeland MA, Shumaker SA, Henderson VW, Brunner RL, Manson JE, Gass ML, Stefanick ML, Lane DS, Hays J, Johnson KC, Coker LH, Dailey M, Bowen D (2003) Effect of estrogen plus progestin on global cognitive function in postmenopausal women: the Women's Health Initiative Memory Study: a randomized controlled trial. JAMA 289:2663-2672.

Sanchez-Simon FM, Arenzana FJ, Rodriguez RE (2010) In vivo effects of morphine on neuronal fate and opioid receptor expression in zebrafish embryos. Eur J Neurosci 32:550-559.

Schneider LS, Finch CE (1997) Can estrogens prevent neurodegeneration? Drugs Aging 11:87-95.

Shumaker SA, Legault C, Rapp SR, Thal L, Wallace RB, Ockene JK, Hendrix SL, Jones BN, 3rd, Assaf AR, Jackson RD, Kotchen JM, WassertheilSmoller S, Wactawski-Wende J (2003) Estrogen plus progestin and the incidence of dementia and mild cognitive impairment in postmenopausal women: the Women's Health Initiative Memory Study: a randomized controlled trial. JAMA 289:2651-2662.

Trinchese F, Liu S, Battaglia F, Walter S, Mathews PM, Arancio O (2004) Progressive age-related development of Alzheimer-like pathology in APP/ PS1 mice. Ann Neurol 55:801-814.

Wagner EJ, Ronnekleiv OK, Kelly MJ (1998) Protein kinase A maintains cellular tolerance to mu opioid receptor agonists in hypothalamic neurosecretory cells with chronic morphine treatment: convergence on a common pathway with estrogen in modulating mu opioid receptor/effector coupling. J Pharmacol Exp Ther 285:1266-1273.

Yaffe K, Sawaya G, Lieberburg I, Grady D (1998) Estrogen therapy in postmenopausal women: effects on cognitive function and dementia. JAMA 279:688-695.

Zhang Y, McLaughlin R, Goodyer C, LeBlanc A (2002) Selective cytotoxicity of intracellular amyloid beta peptide1-42 through p53 and Bax in cultured primary human neurons. J Cell Biol 156:519-529.

Zhang Y, Champagne N, Beitel LK, Goodyer CG, Trifiro M, LeBlanc A (2004) Estrogen and androgen protection of human neurons against intracellular amyloid betal-42 toxicity through heat shock protein 70 . J Neurosci 24:5315-5321.

Zhang Y, Chen Q, Yu LC (2008) Morphine: a protective or destructive role in neurons? Neuroscientist 14:561-570.

Zhao P, Huang Y, Zuo Z (2006) Opioid preconditioning induces opioid receptor-dependent delayed neuroprotection against ischemia in rats. J Neuropathol Exp Neurol 65:945-952.

Zhou Q, Krebs JF, Snipas SJ, Price A, Alnemri ES, Tomaselli KJ, Salvesen GS (1998) Interaction of the baculovirus anti-apoptotic protein p35 with caspase-specificity, kinetics, and characterization of the caspase/p35 complex. Biochemistry 37:10757-10765.

Zwain IH, Yen SS (1999) Neurosteroidogenesis in astrocytes, oligodendrocytes, and neurons of cerebral cortex of rat brain. Endocrinology 140: 3843-3852. 